\title{
ASIC1a Activation Enhances Inhibition in the Basolateral Amygdala and Reduces Anxiety
}

\author{
Volodymyr I. Pidoplichko, ${ }^{1 \star}$ Vassiliki Aroniadou-Anderjaska, ${ }^{1,2,3 \star}$ Eric M. Prager, ${ }^{1,3}$ Taiza H. Figueiredo, ${ }^{1}$ \\ Camila P. Almeida-Suhett, ${ }^{1,3}$ Steven L. Miller, ${ }^{1,3}$ and Maria F. M. Braga ${ }^{1,2,3}$ \\ ${ }^{1}$ Department of Anatomy, Physiology, and Genetics, ${ }^{2}$ Department of Psychiatry, and ${ }^{3}$ Program in Neuroscience, F. Edward Hébert School of Medicine, \\ Uniformed Services University of the Health Sciences, Bethesda, Maryland 20814
}

\begin{abstract}
The discovery that even small changes in extracellular acidity can alter the excitability of neuronal networks via activation of acid-sensing ion channels (ASICs) could have therapeutic application in a host of neurological and psychiatric illnesses. Recent evidence suggests that activation of ASIC1a, a subtype of ASICs that is widely distributed in the brain, is necessary for the expression of fear and anxiety. Antagonists of ASIC1a, therefore, have been proposed as a potential treatment for anxiety. The basolateral amygdala (BLA) is central to fear generation, and anxiety disorders are characterized by BLA hyperexcitability. To better understand the role of ASIC1a in anxiety, we attempted to provide a direct assessment of whether ASIC1 a activation increases BLA excitability. In rat BLA slices, activation of ASIC1a by low $\mathrm{pH}$ or ammonium elicited inward currents in both interneurons and principal neurons, and increased spontaneous IPSCs recorded from principal cells significantly more than spontaneous EPSCs. Epileptiform activity induced by high potassium and low magnesium was suppressed by ammonium. Antagonism of ASIC1a decreased spontaneous IPSCs more than EPSCs, and increased the excitability of the BLA network, as reflected by the pronounced increase of evoked field potentials, suggesting that ASIC1a channels are active in the basal state. In vivo activation or blockade of ASIC1a in the BLA suppressed or increased, respectively, anxiety-like behavior. Thus, in the rat BLA, ASIC1a has an inhibitory and anxiolytic function. The discovery of positive ASICla modulators may hold promise for the treatment of anxiety disorders.
\end{abstract}

Key words: basolateral amygdala; acid-sensing ion channels; ASIC1a; GABAergic inhibition; epileptiform activity; anxiety

\section{Introduction}

The existence of an inward current activated by lowering extracellular $\mathrm{pH}$ and carried by $\mathrm{Na}^{+}$and $\mathrm{K}^{+}$was first reported in rat spinal ganglia and trigeminal nerve ganglion by Krishtal and $\mathrm{Pi}$ doplichko, in 1980. A cation channel with these biophysical properties was later cloned from cDNA isolated from rat brain, and was named ASIC for acid-sensing ionic channel (Waldmann et al., 1997). Three types of ASICs have been cloned so far: ASIC1, ASIC2, and ASIC3 (Waldmann and Lazdunski, 1998). All three proton-gated channels are members of the degenerin/epithelial $\mathrm{Na}^{+}$channel family, but have different biophysical properties and regional distribution (Waldmann and Lazdunski, 1998). The ASIC1 has two splice variants: ASIC1a and ASIC1b. The ASIC1b

Received Sept. 18, 2013; revised Dec. 11, 2013; accepted Dec. 30, 2013.

Author contributions:V.I.P., V.A.-A., and M.F.M.B. designed research;V.I.P., V.A.-A., E.M.P., T.H.F., C.P.A.-S., and S.L.M. performed research; V.I.P., V.A.-A., E.M.P., T.H.F., C.P.A.-S., S.L.M., and M.F.M.B. analyzed data; V.A.-A. and M.F.M.B. wrote the paper.

This work was supported by the CounterACT Program, National Institutes of Health, Office of the Director and the National Institute of Neurologic Disorders and Stroke (Grant Number 5U01NS058162-07) and the Defense Threat Reduction Agency-Joint Science and Technology Office, Medical S\&T Division (Grant Numbers CBM.NEURO.01.10.US.18 and (BM.NEURO.01.10.US.15).

*V.I.P. and V.A.-A. contributed equally to this work.

The authors have no competing financial interests.

Correspondence should be addressed to Dr. Maria F.M. Braga, Department of Anatomy, Physiology, and Genetics, Uniformed Services University of the Health Sciences, 4301 Jones Bridge Road, Bethesda, MD 20814. E-mail: maria.braga@usuhs.edu.

DOI:10.1523/JNEUROSCI.4009-13.2014

Copyright $\odot 2014$ the authors $\quad 0270-6474 / 14 / 343130-12 \$ 15.00 / 0$ is expressed only in sensory neurons (Chen et al., 1998), whereas the ASIC1a is widely expressed in the brain, with the highest expression levels found in the amygdala, the main olfactory bulb, cerebral cortex, hippocampus, habenula, and cerebellum (Waldmann et al., 1997; Biagini et al., 2001).

It is unclear whether activation of ASICla enhances or suppresses the activity and excitability of the neuronal networks where the channel is expressed. A preferential enhancement of inhibition is suggested by the evidence that activation of these channels plays an important role in seizure termination in mice, in vivo (Ziemann et al., 2008), suppresses epileptiform activity in mouse hippocampal slices (Ziemann et al., 2008), and evokes larger currents in dissociated hippocampal interneurons than in CA1 pyramidal cells, isolated from rats (Bolshakov et al., 2002) or mice (Ziemann et al., 2008). However, behavioral studies seem to suggest that in the amygdala, a brain region that plays a central role in emotional behavior (Phelps and LeDoux, 2005) and associated disorders - such as anxiety disorders (Rauch et al., 2000; Shekhar et al., 2003; Etkin and Wager, 2007; Stein and Stein, 2008) - the function of the ASIC1a is to promote hyperexcitability, rather than to enhance inhibition. Thus, genetic elimination or pharmacological blockade of ASIC1a, in mice, reduces fear (Coryell et al., 2007; Ziemann et al., 2009) and has antidepressant (Coryell et al., 2009) and anxiolytic effects (Dwyer et al., 2009). Fear and anxiety are associated with hyperactivity and hyperexcitability of the basolateral amygdala (BLA; Gonzalez et al., 1996; 
Sajdyk and Shekhar, 1997; Vazdarjanova et al., 2001; Shekhar et al., 2003; Braga et al., 2004; Gale et al., 2004; AroniadouAnderjaska et al., 2007; Zhou et al., 2010; Wang et al., 2011). It was not surprising, therefore, that localized ASICla expression in the BLA of ASICla-null mice restored the fear behavior induced by $\mathrm{CO}_{2}$ inhalation (Ziemann et al., 2009). The implication of these behavioral studies is that the function of ASICla in the BLA is to promote hyperactivity. Accordingly, it was suggested that ASICla antagonists must receive consideration as a potential treatment for anxiety (Coryell et al., 2007; Dwyer et al., 2009) and depression (Coryell et al., 2009). However, so far there has been no direct evidence that blockade of ASICla suppresses amygdalar excitability. In the present study, we investigated the role that ASICla channels play in the regulation of neuronal excitability in the BLA.

\section{Materials and Methods}

\section{Electrophysiological experiments}

Male, Sprague Dawley rats (25 to $40 \mathrm{~d}$ old) were anesthetized with isoflurane before decapitation. Coronal brain slices (400 $\mu \mathrm{m}$ thick) containing the amygdala were cut as described previously (AroniadouAnderjaska et al., 2012). Recording solution (artificial CSF, ACSF) consisted of the following (in $\mathrm{mM}$ ): $125 \mathrm{NaCl}, 2.5 \mathrm{KCl}, 1.25 \mathrm{NaH}_{2} \mathrm{PO}_{4}, 21$ $\mathrm{NaHCO}_{3}, 2 \mathrm{CaCl}_{2}, 1 \mathrm{MgCl}_{2}$, and $11 \mathrm{D}$-glucose (for field potential recordings, $1.5 \mathrm{mM} \mathrm{MgCl}_{2}$ and $3 \mathrm{~mm} \mathrm{KCl}$ was used). All solutions were saturated with $95 \% \mathrm{O}_{2}, 5 \% \mathrm{CO}_{2}$ to achieve a $\mathrm{pH}$ near 7.4. For whole-cell recordings, the slice chamber ( $0.7 \mathrm{ml}$ capacity) had continuously flowing ACSF $(\sim 8 \mathrm{ml} / \mathrm{min})$ at temperature $31-32^{\circ} \mathrm{C}$, except for a few experiments where the bath temperature was reduced to $27^{\circ} \mathrm{C}$, as indicated in the results. The osmolarity of the external solution was adjusted to 325 mOsm with D-glucose. Field potential recordings were obtained in an interface-type chamber, maintained at $\sim 32^{\circ} \mathrm{C}$, with a flow rate of the ACSF at $1.5 \mathrm{ml} / \mathrm{min}$.

Whole-cell recordings were obtained as described previously (Williams et al., 2011; Aroniadou-Anderjaska et al., 2012). Patch electrodes were filled with the following (in mM): $60 \mathrm{CsCH}_{3} \mathrm{SO}_{3}, 60 \mathrm{KCH}_{3} \mathrm{SO}_{3}, 10$ $\mathrm{KCl}, 10$ EGTA, 10 HEPES, $5 \mathrm{Mg}$-ATP, and $0.3 \mathrm{Na}_{3} \mathrm{GTP}, \mathrm{pH} 7.2,290$ mOsm. When recordings were obtained in the absence of CNQX, the internal chloride concentration was $1 \mathrm{~mm}$, and osmolarity was adjusted with potassium gluconate. Tight-seal $(>1 G \Omega)$ whole-cell recordings were obtained from the cell body of interneurons and pyramidal-shaped neurons in the BLA region. We distinguished interneurons from principal cells based on size and shape (larger size and pyramidal shape for principal cells), as well as on their electrophysiological characteristics. The majority of BLA interneurons fire fast, nonaccommodating action potentials in response to depolarizing current pulses, while principal cells fire longer duration action potentials displaying various patterns of accommodation (Sah et al., 2003; Sosulina et al., 2010). In addition, a significant proportion of interneurons demonstrate linear change in leakage current in response to hyperpolarizing voltage steps, in contrast to the principal BLA neurons, which display a hyperpolarizationactivated cationic current $\left(I_{\mathrm{h}}\right.$; Womble and Moises, 1993; Park et al., 2007; Aroniadou-Anderjaska et al., 2012). Access resistance (15-24 M $\Omega$ ) was regularly monitored during recordings, and cells were rejected if the resistance changed by $>15 \%$ during the experiment.

Agonists or antagonists of ASICla were applied either to the bath or by pressure injection (Pidoplichko and Dani, 2005). Pressure was applied to the pipette via a Picospritzer (General Valve Division, Parker Hannifin), set at $\sim 100 \mathrm{kPa}$ (14 psi). A motorizer (Newport) was coupled with the approach/withdrawal (push-pull) actuator of a micromanipulator (Burleigh PCS-5000 series; EXFO Photonic Solution). Motorizer movement and duration of application pulses were controlled with a Master-8 digital stimulator (AMPI). Ionic currents and action potentials were amplified and filtered $(1 \mathrm{kHz})$ using the Axopatch 200B amplifier (Molecular Devices) with a four-pole, low-pass Bessel filter, were digitally sampled (up to $2 \mathrm{kHz}$ ) using the pClamp 10.2 software (Molecular Devices), and further analyzed using the Mini Analysis program (Synaptosoft) and Origin (OriginLab).

Field potentials were evoked by single-pulse stimulation of the external capsule at $0.05 \mathrm{~Hz}$, as described previously (AroniadouAnderjaska et al., 2012). Signals were digitized using the pClamp 10.2 software (Molecular Devices), analyzed using Clampfit 10.2, and final presentation was prepared using Origin (OriginLab) or Graphpad Prism (GraphPad Software).

Drugs used were as follows: CNQX, an AMPA/kainate receptor antagonist; bicuculline methiodide, a $\mathrm{GABA}_{\mathrm{A}}$ receptor antagonist; and ammonium chloride, an activator of ASICla (Pidoplichko and Dani, 2006; all from Sigma-Aldrich); D-AP5, an NMDA receptor antagonist; $\mathrm{SCH} 50911$, a $\mathrm{GABA}_{\mathrm{B}}$ receptor antagonist; and flurbiprofen, an ASICla antagonist (Voilley et al., 2001; all from Tocris Bioscience); tarantula venom psalmotoxin (PcTX1, $100 \mu$ l lyophilized milked venom; Spider Pharm), an ASIC1a antagonist (Escoubas et al., 2000; Baron et al., 2002; Diochot et al., 2007); and synthetic psalmotoxin 1 (Peptides International), an ASICla antagonist. Low $\mathrm{pH}$ solutions for bath application were prepared as described by Ziemann et al. (2008), except that sodium bicarbonate content was lowered to $5 \mathrm{~mm}$ to yield a $\mathrm{pH}$ of 6.6. Solutions with $\mathrm{pH} 5.0$ for pressure application were buffered with HEPES. Osmolarity was adjusted by adding sodium gluconate.

\section{Behavioral experiments}

Subjects. Male, Sprague Dawley rats (40 to $45 \mathrm{~d}$ old) were individually housed in an environmentally controlled room $\left(20-23^{\circ} \mathrm{C}, 12 \mathrm{~h}\right.$ light/ dark cycle, lights on 06:00 P.M.), with food and water available ad libitum. All experimental procedures adhered to the National Institutes of Health Guide for the Care and Use of Laboratory Animals, and were approved by the Institutional Animal Care and Use Committee of the Uniformed Services University of the Health Sciences.

Surgical procedure. Forty rats were anesthetized with 2-5\% isoflurane, using a KSC Anesthesia System (Kent Scientific). Each rat was mounted on a stereotaxic frame (David Kopf Instruments), and a midline incision was made over the skull. The skull was scraped clean, four holes were then drilled into the skull, and self-tapping stainless steel screws were inserted to help anchor the guide cannulae (Plastics One). Next, two additional sites were drilled, and stainless steel guide cannulae (26 gauge; Plastic One) of $8.0 \mathrm{~mm}$ length were implanted at the following coordinates: 2.8 $\mathrm{mm}$ anteroposterior to the bregma, $4.6 \mathrm{~mm}$ lateral to the midline, and 8.0 $\mathrm{mm}$ in depth (based on Paxinos and Watson, 2005). Dental cement (A-M Systems) was used to affix the guide cannulae and to stabilize the assembly by adhering to the four stainless steel screws.

Microinjection procedure. Beginning on the seventh day following surgery, each rat was extensively handled by the experimenter for $3 \mathrm{~d}$. During the following $3 \mathrm{~d}$, the rats were gently restrained by hand, and injection tubing (Plastics One) was screwed in the animals' head, while an electric pump was turned on, to habituate the rats to the handling and noises associated with the microinjection procedure. On experimental days, 33 gauge injector cannulae were inserted into the guide cannulae. The injectors were $9 \mathrm{~mm}$ length (to extend $1 \mathrm{~mm}$ beyond the end of the guide cannulae). Drug solutions were bilaterally infused for $2 \mathrm{~min}$, at a rate of $0.5 \mu \mathrm{l} / \mathrm{min}$, using a microinfusion pump (Harvard Apparatus); 1 $\mu \mathrm{l}$ total volume was delivered in the BLA of each hemisphere. Injectors were left in place for $1 \mathrm{~min}$ after the end of the infusion. In the open field test (see next paragraph), each rat was tested only with a single dose of one of three drugs (ammonium chloride, synthetic psalmotoxin, and tarantula venom psalmotoxin; all dissolved in ACSF) and a single dose of the vehicle (ACSF); the two tests were separated by 1 week, and the order of testing was randomized.

Open field test. Behavioral tests took place during the dark phase of the rats' light/dark cycle. Anxiety-like behavior was assessed using an open field apparatus $(40 \times 40 \times 30 \mathrm{~cm}$ clear Plexiglas arena $)$. The animals were acclimated to the apparatus in one session. On test days, the rats were placed in the center of the open field, 5 min after drug or vehicle injection. Activity was measured and recorded for $5 \mathrm{~min}$, using an AccuScan Electronics infrared photocell system (AccuScan Instruments). Data were automatically collected and transmitted to a computer equipped with "Fusion" software (AccuScan Electronics). Locomotion (distance 
traveled in centimeters), total movement time, and time spent in the center of the open field were analyzed. Anxiety behavior was measured as the ratio of the time spent in the center over the total movement time, expressed as a percentage of the total movement time.

Light/dark box test. Anxiety-like behavior was also assessed using a light/dark box apparatus, which consisted of an activity arena that was fitted with a light/dark box insert (AccuScan Instruments). The light and dark compartments measured $20 \times 40 \times 30 \mathrm{~cm}$ each. Approximately $5 \mathrm{~min}$ after drug or vehicle microinjection, rats were placed in the light compartment facing the dark compartment, and their activity was recorded for $5 \mathrm{~min}$, using an AccuScan Electronics infrared photocell system. Anxiety behavior was assessed by the latency to enter the dark compartment and the time spent in the light compartment.

Histology. After completion of the behavioral tests, rats were anesthetized with isoflurane using a KSC Anesthesia System (Kent Scientific) and injected into each BLA with $1 \mu \mathrm{l}$ of vehicle (ACSF) containing $5 \mathrm{~mm}$ methylene blue (using the same procedure as with drug injection), before decapitation. The brains were removed and stored in $4 \%$ paraformaldehyde for at least $7 \mathrm{~d}$, then moved to a solution of $30 \%$ sucrose in PBS for $72 \mathrm{~h}$, before being sectioned on a freezing microtome (40 $\mu \mathrm{m} \mathrm{sec-}$ tions). Brain sections were mounted onto slides, and stained with cresyl violet according to standard procedures. The location of the guide cannulae and the spread of the infused dye were determined using a light microscope. Only rats with confirmed injection limited to the BLA ( 41 of 55 rats) were used in the results analysis.

\section{Statistical analysis}

The results from the electrophysiological and behavioral experiments were tested for statistical significance using the independent $t$ test or paired $t$ test. Differences were considered significant when $p<0.05$. Data are presented as mean \pm SE. Sample size $n$ refers to the number of neurons for the whole-cell experiments, the number of slices for the field potential recordings, and the number of animals for the behavioral experiments.

\section{Results}

ASIC1a channels are present on both interneurons and principal cells

Our first aim was to determine whether interneurons and principal neurons in the BLA carry functional ASIC1a channels. We have previously demonstrated that in addition to being gated by protons, the ASICla is also gated by ammonium (Pidoplichko, 1992; Pidoplichko and Dani, 2006). Therefore, to determine whether ASICla channels are present on BLA interneurons, we pressure applied acidified ACSF, pH 5, or ACSF containing $40 \mathrm{~mm}$ ammonium chloride, while recording from interneurons $(n=9)$ at a holding potential $\left(V_{\mathrm{h}}\right)$ of $-70 \mathrm{mV}$, and in the presence of CNQX $(10 \mu \mathrm{M})$, D-AP5 $(50 \mu \mathrm{M})$, and bicuculline $(20 \mu \mathrm{M})$. Both low $\mathrm{pH}$ and ammonium induced inward currents that were dramatically enhanced

a

b

C

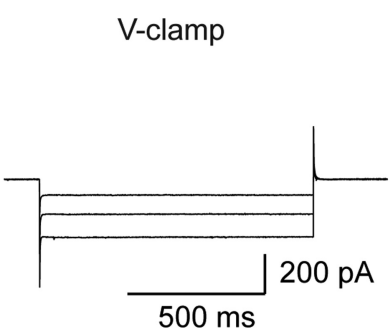

$\mathrm{V}_{\mathrm{m}}(\mathrm{mV})$

C-clamp
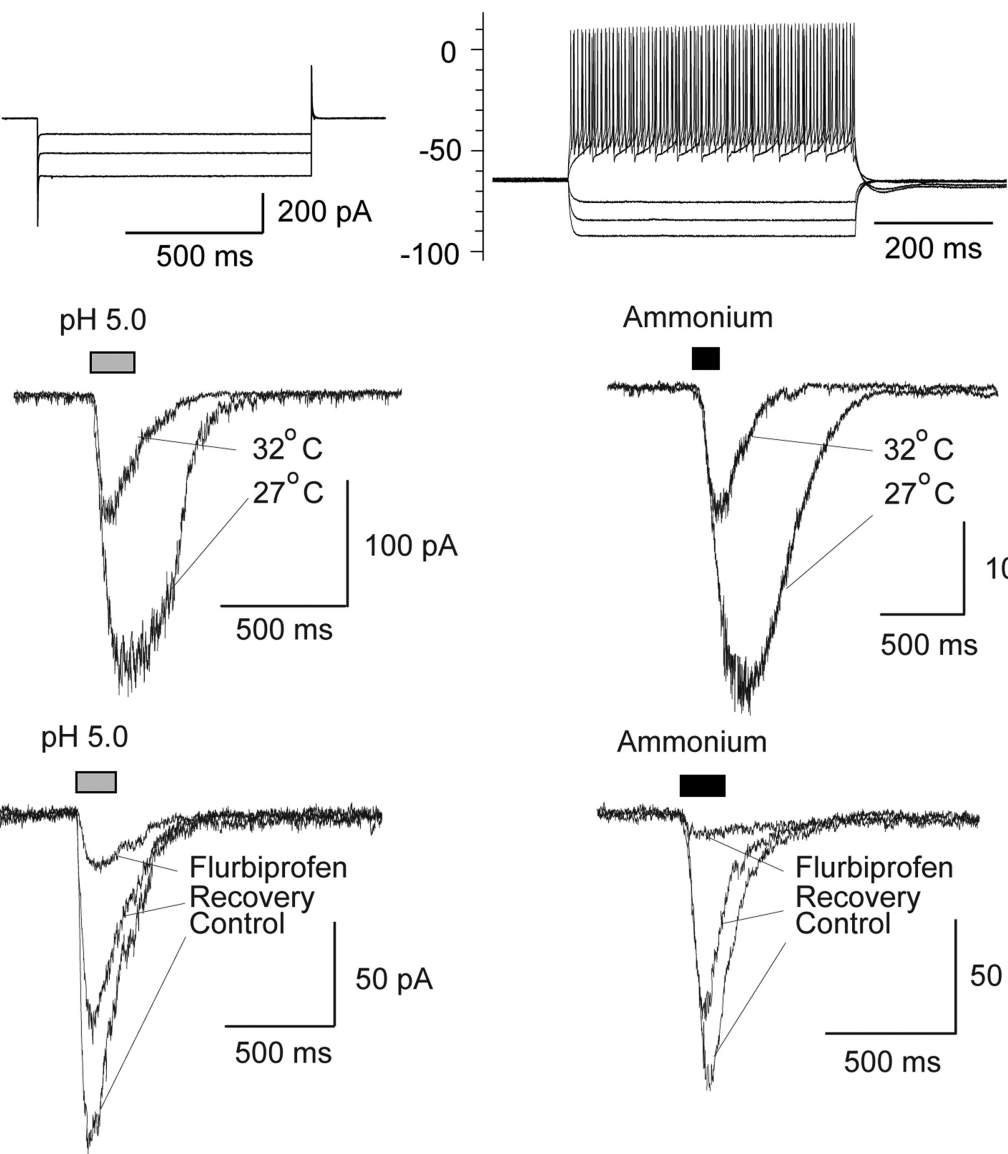

$-100-$

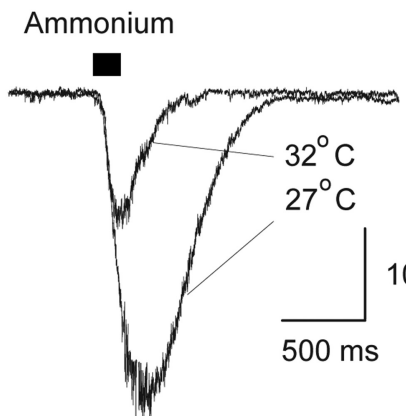

$100 \mathrm{pA}$
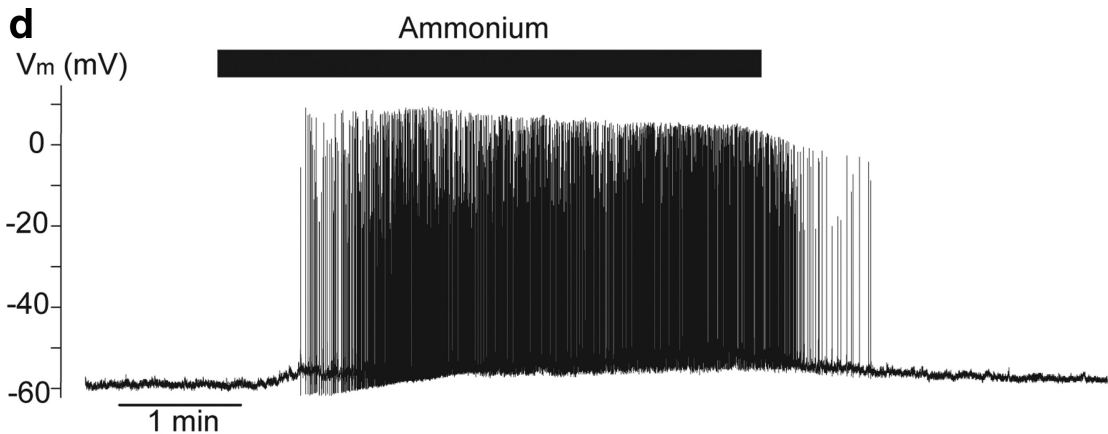

Figure 1. ASIC1a channels are present on BLA interneurons. $\boldsymbol{a}$, Typical linear currents $\left(I_{\mathrm{h}}\right.$ is absent) recorded from presumed interneurons in response to $1 \mathrm{~s}$ long hyperpolarizing voltage steps ( $10 \mathrm{mV}$ increments from the holding potential of $-70 \mathrm{mV}$ ) in voltage-clamp (V-clamp) mode (left), and an example of fast, nonaccommodating spiking of interneurons in response to $500 \mathrm{~ms}$ long current injections in the current-clamp (C-clamp) mode (right). $\boldsymbol{b}$, Brief (200 ms) pressure application of acidified solution (left) or $40 \mathrm{~mm}$ ammonium (right) induced inward currents in interneurons, which were increased by lowering the bath temperature. c, Currents evoked by acidified solution or $40 \mathrm{~mm}$ ammonium were blocked by bath-applied flurbiprofen $(2 \mathrm{~mm})$. $\boldsymbol{d}$, In the current-clamp mode, bath application of $5 \mathrm{~mm}$ ammonium-induced high-frequency firing. $\operatorname{In} \boldsymbol{b}$ and $\boldsymbol{c}, V_{\mathrm{h}}$ is $-70 \mathrm{mV}$. In $\boldsymbol{b}, \boldsymbol{c}$, and $\boldsymbol{d}$, recordings are in the presence of CNQX (10 $\mu \mathrm{M})$, D-AP5 $(50 \mu \mathrm{M})$, bicuculline $(20 \mu \mathrm{M})$, and SCH50911 (10 $\mu \mathrm{M})$.

when the temperature of the bathing solution was reduced from 32 to $27^{\circ} \mathrm{C}$ (Fig. $1 \mathrm{~b}$ ), which is consistent with the paradoxical temperature dependency of ASICla channels (Askwith et al., 2001). The evoked currents were reversibly blocked by bath application of the ASIC1a antagonist flurbiprofen (Fig. 1c). In the current-clamp mode, bath application of $5 \mathrm{~mm}$ ammonium induced highfrequency firing of the recorded interneurons $(n=4$; Fig. $1 d)$. These data indicate that ASICla channels are present on BLA interneurons, and their activation produces strong depolarization. 
a

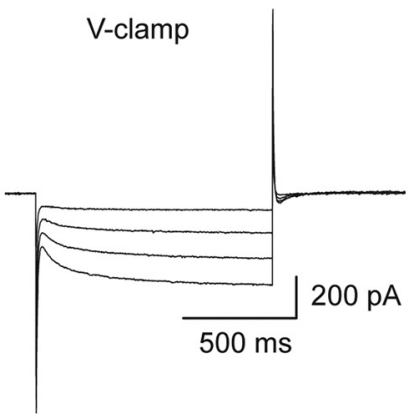

b

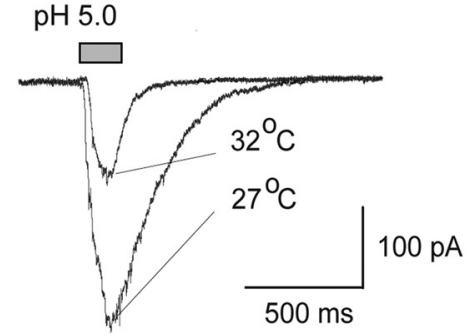

C $\quad \mathrm{pH} 5.0$

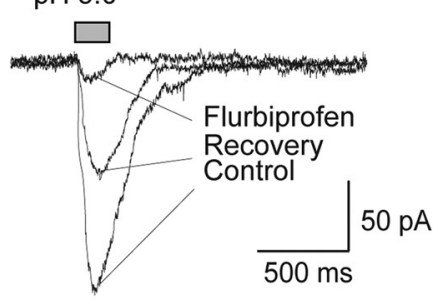

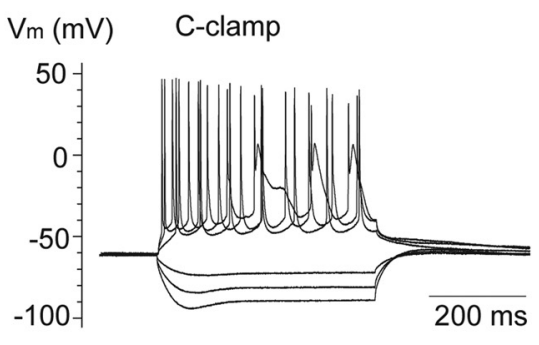
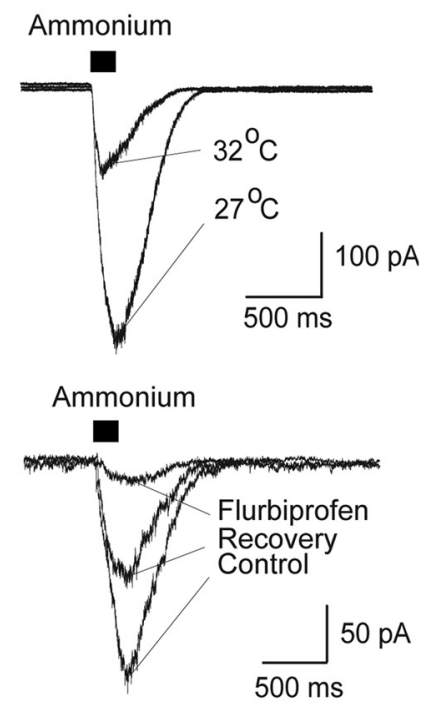

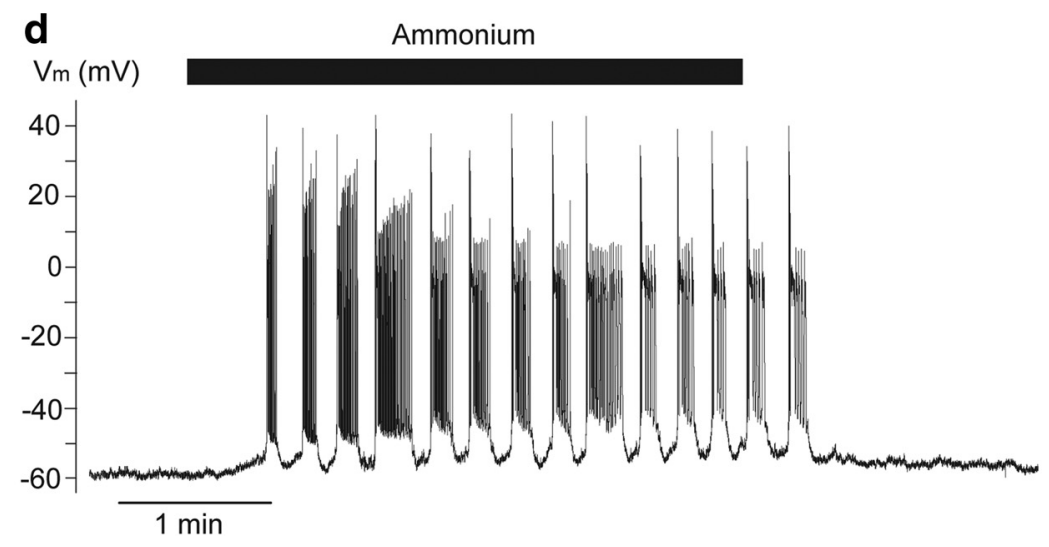

Figure 2. ASIC1a channels are present on BLA principal neurons. $\boldsymbol{a}$, Currents recorded from principal neurons in response to hyperpolarizing voltage steps in voltage-clamp (V-clamp) mode (left; notice the presence of $/ \mathrm{h}$ ), and an example of accommodating firing in response to current injection in the current-clamp (C-clamp) mode (right). $\boldsymbol{b}$, Pressure application ( $200 \mathrm{~ms}$ ) of acidified solution (left) or $40 \mathrm{~mm}$ ammonium (right) induced inward currents in principal cells, which were increased by lowering the bath temperature. c, Currents evoked in principal cells by acidified solution or $40 \mathrm{~mm}$ ammonium were blocked by bath-applied flurbiprofen $(2 \mathrm{mM})$. $\boldsymbol{d}$, In the current-clamp mode, bath application of $5 \mathrm{~mm}$ ammonium induced bursts of action potentials. $\ln \boldsymbol{b}$ and $\boldsymbol{c}, V_{\mathrm{h}}$ is $-70 \mathrm{mV}$. In $\boldsymbol{b}, \boldsymbol{c}$, and $\boldsymbol{d}$, recordings are in the presence of CNQX (10 $\mu \mathrm{m}), \mathrm{D}-\mathrm{AP5}(50 \mu \mathrm{M})$, bicuculline $(20 \mu \mathrm{M})$, and SCH50911 (10 $\mu \mathrm{M})$.

Next, we examined if principal neurons in the BLA also carry ASICla channels. Pressure application of either acidified ACSF of pH $5.0(n=27)$, or ACSF containing $40 \mathrm{~mm}$ ammonium $(n=24)$ induced inward currents in principal cells, which were enhanced when the temperature of the bathing solution was reduced from 32 to $27^{\circ} \mathrm{C}$ (Fig. $2 b$ ), and were reversibly blocked by bath-applied flurbiprofen (Fig. 2c). In the current-clamp mode, bath application of ammonium $(5 \mathrm{~mm})$ induced repetitive bursts of action potentials $(n=5$; Fig. $2 d)$. Thus, BLA principal neurons also express functional ASIC1a channels.
The effects of ASIC1a activation or blockade on spontaneous inhibitory activity

The presence of ASIC1a on interneurons, presumed to be GABAergic, predicts that activation of these channels will increase GABAergic activity in the BLA network. Indeed, bath application of $5 \mathrm{~mm}$ ammonium, in the presence of CNQX $(10 \mu \mathrm{M})$, D-AP-5 (50 $\mu \mathrm{M})$, and SCH50911 (10 $\mu \mathrm{M})$ increased the frequency of spontaneous IPSCs (sIPSCs) recorded from principal neurons, from $25 \pm 2$ to $36 \pm 3 \mathrm{~Hz}(n=$ $11, t_{(10)}=4.87, p=0.0006$; Fig. $\left.3 a-c\right)$. Similarly, perfusion of the slices with acidified ASCF, $\mathrm{pH}$ 6.6, increased the frequency of sIPSCs from $17 \pm 2$ to $24 \pm 1$ $\mathrm{Hz}\left(n=8, t_{(7)}=8.10, p=0.000008\right.$; Fig. $3 d-f)$.

Since ASICla activation enhances sIPSCs, we asked whether these channels are also active in the basal state, contributing to the tonic level of inhibition ("background" inhibition due to spontaneous GABA release) in the BLA. To answer this question, we recorded sIPSCs from principal BLA neurons, and then bath-applied either flurbiprofen, or the tarantula venom, PcTx1, which specifically block homomeric ASICla channels (Escoubas et al., 2000; Voilley et al., 2001; Baron et al., 2002; Diochot et al., 2007). Both compounds significantly decreased the frequency and amplitude of sIPSCs; flurbiprofen decreased the frequency of sIPSCs from $26 \pm 2$ to $7 \pm 2 \mathrm{~Hz}\left(n=7, t_{(6)}=\right.$ 13.22, $p=0.00001$; Fig. $4 a-c$ ), whereas PcTX1 decreased sIPSCs from $38 \pm 2$ to $24 \pm 3 \mathrm{~Hz}\left(n=4, t_{(3)}=7.30, p=0.005\right.$; Fig. $4 d-f$ ). To be certain that flurbiprofen or PcTX1 did not have a direct suppressive effect on GABAergic synaptic transmission, we also evoked GABA currents by pressure application of GABA on the recorded principal neurons. Neither flurbiprofen nor PcTX1 had any significant effect on the GABA-evoked currents at the time that these drugs suppressed sIPSCs (Fig. 4a,d). These data suggest that ASICla channels are active during basal synaptic activity and contribute significantly to the generation of sIPSCs. We should note here that we also attempted to antagonize the activity of ASIC1a with amiloride (Waldmann et al., 1997; Voilley et al., 2001) or nafamostat mesylate (Ugawa et al., 2007), but found that these compounds directly affect GABAergic transmission; currents evoked by pressure application of GABA were reduced by $\sim 40 \%$ and $90 \%$ in the presence of amiloride and nafamostat mesylate, respectively. Furthermore, in consistency with previous observations that only certain nonsteroidal anti-inflammatory drugs interact with ASICs, via a COX-independent mechanism (Voilley et al., 2001), we found 
that the effects of flurbiprofen were not mimicked by acetaminophen $(2 \mathrm{~mm})$.

\section{ASICla activation increases \\ glutamatergic excitation of interneurons}

Considering that in addition to GABAergic cells, principal BLA neurons also have functional ASICla channels, we examined if under acidic conditions, interneurons are not depolarized only directly by activation of ASICla, but also due to glutamatergic excitation secondarily to ASICla-mediated depolarization of principal cells. When we recorded spontaneous EPSCs (sEPSCs) from BLA interneurons, perfusion of the slices with acidified solution increased the frequency of sEPSCs from $19 \pm 3$ to $25 \pm$ $3 \mathrm{~Hz}(n=4, p=0.01023$; Fig. $5 a)$. When we recorded currents evoked by pressure application of acidified solution in the absence of CNQX, sEPSCs were present, overlapping with the evoked currents $(n=4$; Fig. $5 b)$. The frequency of sEPSCs recorded from interneurons was also increased by pressure application of ammonium $(n=4$; Fig. $5 c)$. To determine whether in the basal state ASICla activity on principal cells contributes to glutamatergic excitation of interneurons, we recorded sEPSCs from interneurons, and then bath applied flurbiprofen; the frequency of sEPSCs was reduced by flurbiprofen from $20 \pm 3$ to $5 \pm 1 \mathrm{~Hz}(n=4$, $p=0.00528$; Fig. $5 d$ ). Thus, activation of ASIC1a channels depolarizes interneurons not only directly, but also indirectly due to glutamate release from principal cells, and this mechanism is in effect also in the basal state.

\section{The net effect of ASIC1a activation on BLA excitability}

The results described above demonstrate that activation of ASICla increases inhibitory activity in the BLA due to direct and indirect (via synaptic glutamatergic excitation) depolarization of interneurons. However, ASICla activation can be expected to also increase excitatory activity, since principal neurons also carry these channels. The question, therefore, arises as to what would be the net effect of ASIC1a activation on the overall level of activity and excitability of the BLA. To answer this question, first we examined the effect of ASICla activation on sIPSCs and sEPSCs recorded simultaneously from principal cells. To quantify these effects we calculated the total charge transferred. The charge, in picocoulombs, was calculated as the area delimited by the inhibitory or excitatory current and the baseline. Current areas were analyzed for a time window of $5 \mathrm{~s}$. Bath application of ammonium $(5 \mathrm{~mm})$ increased the charge transferred by sIPSCs from $1.4 \pm 0.2$ to $38 \pm 4 \mathrm{pC}\left(n=21, t_{(20)}=\right.$ 9.44, $p=0.000000008$ ), while at the same time the charge trans-
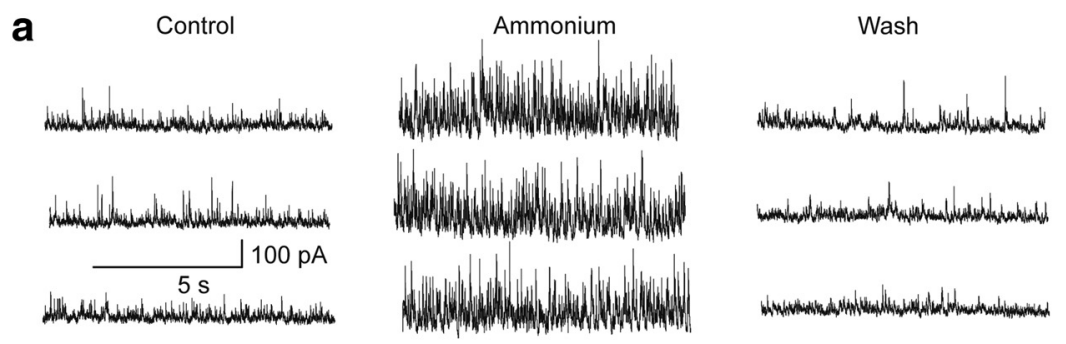

b
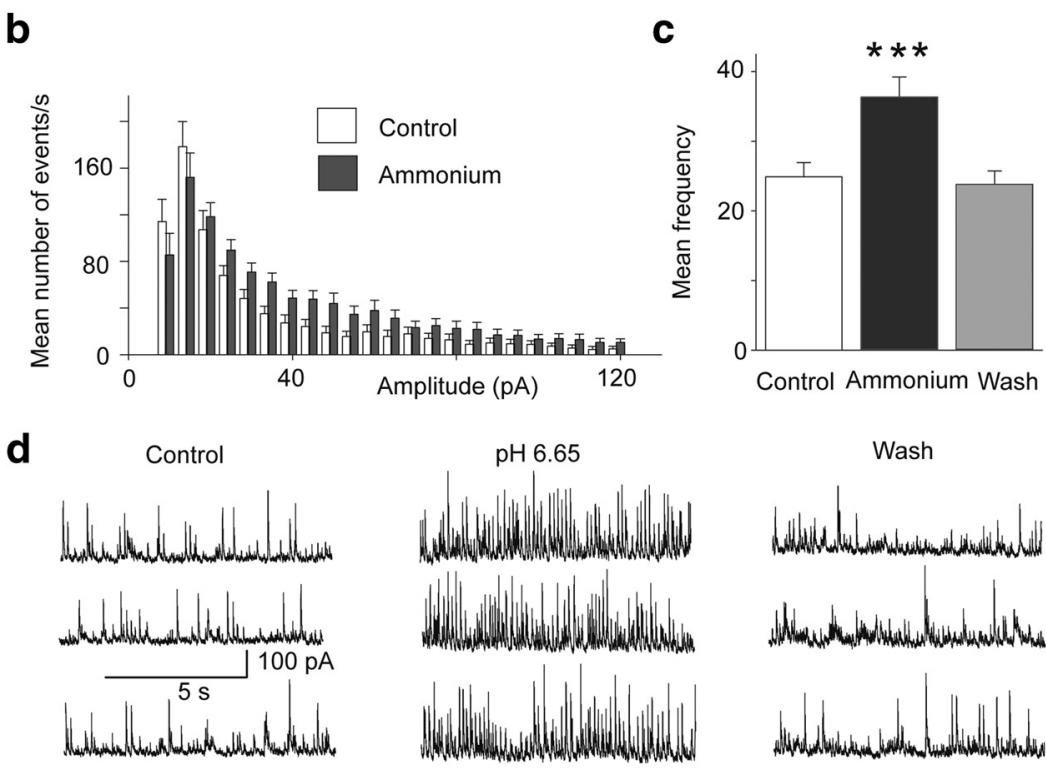

Control

Ammonium
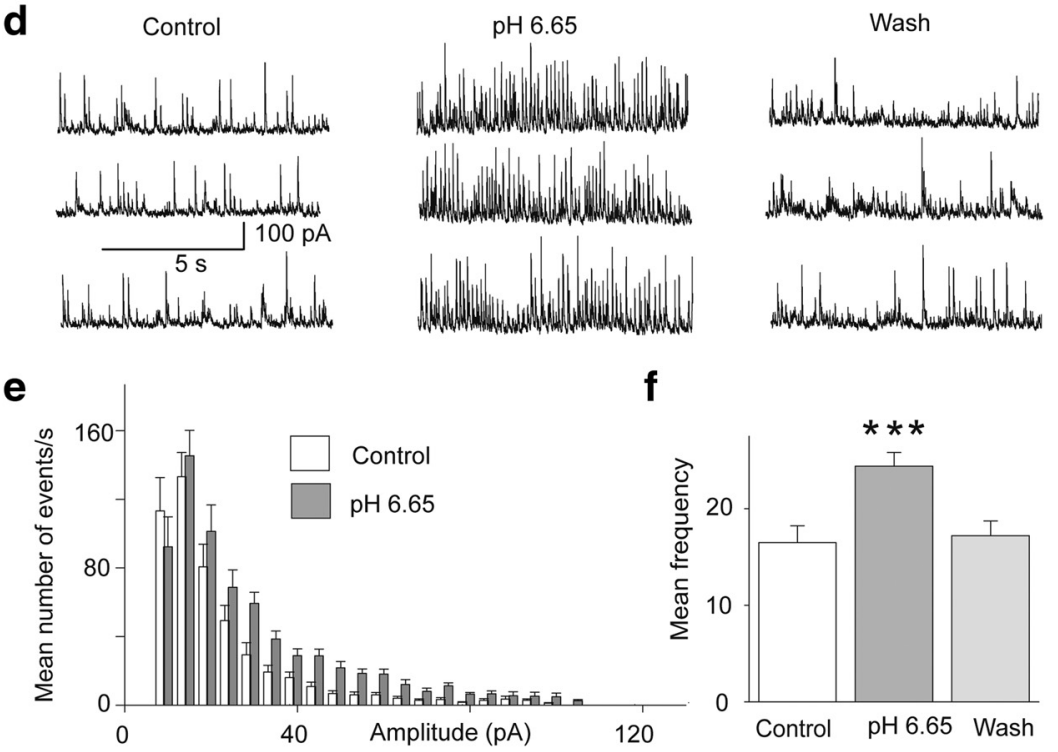

f

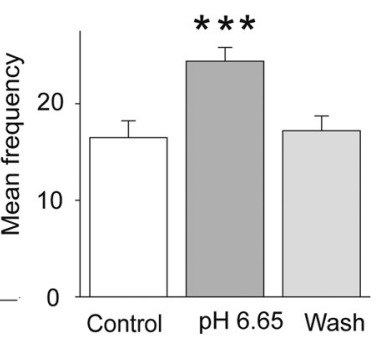

Figure 3. Activation of ASIC1a increases spontaneous inhibitory activity. Recordings were obtained from BLA principal cells in the presence of CNQX (10 $\mu \mathrm{m})$, D-AP5 $(50 \mu \mathrm{m})$, and SCH50911 (10 $\mu \mathrm{m})$, at $V_{\mathrm{h}}=+30 \mathrm{mV}$. $\boldsymbol{a}$, sIPSCs before, during, and after bath application of 5 mm ammonium. $\boldsymbol{b}$, Amplitude-frequency histogram of sIPSC before and after bath application of 5 mm ammonium and after washing out of ammonium $(n=11)$; ${ }^{* *} p<0.001$ when compared with the control. $\boldsymbol{d}$, sIPSCs before, during, and after perfusion of the slices with acidified ACSF. $e$, Amplitude-frequency histogram of sIPSCs in control medium and in pH 6.65 ( $n=8$ neurons from 3 rats); bin width is $5 \mathrm{pA}$. $\boldsymbol{f}$, Group data of the frequency of sIPSCs in control medium, in low pH, and after return to control medium $(n=8) ;{ }^{* * *} p<0.001$ when compared with the control.

ferred by sEPSCs increased from $1.3 \pm 0.1$ to $9 \pm 1 \mathrm{pC}(n=21$, $t_{(20)}=7.45, p=0.0000003$; Fig. $\left.6 a\right)$. The ammonium-induced increase of the charge transferred by sIPSCs (4540 $\pm 1377 \%)$ was significantly greater than that of the $\operatorname{sEPSCs}\left(935 \pm 188 \%\right.$; $t_{(20)}=$ $2.89, p=0.009$ ). Similar effects were observed when slices were perfused with ACSF of $\mathrm{pH}$ 6.6. The acidified solution increased the charge transferred by sIPSCs from $2.1 \pm 0.6$ to $19 \pm 3 \mathrm{pC}(n=$ $\left.9, t_{(8)}=5.58, p=0.0005\right)$, while at the same time the charge transferred by sEPSCs increased from $2.0 \pm 0.5$ to $4.8 \pm 0.6 \mathrm{pC}$ $\left(n=9, t_{(8)}=8.46, p=0.00003\right.$; Fig. $\left.6 b\right)$. Again, the difference between the increase of sIPSCs (1420 $\pm 351 \%)$ and the increase of $\operatorname{sEPSCs}(289 \pm 32 \%)$ was statistically significant $\left(t_{(8)}=3.43, p=\right.$ 0.009). Thus, ASIC1a activation increases both GABAergic and glu- 

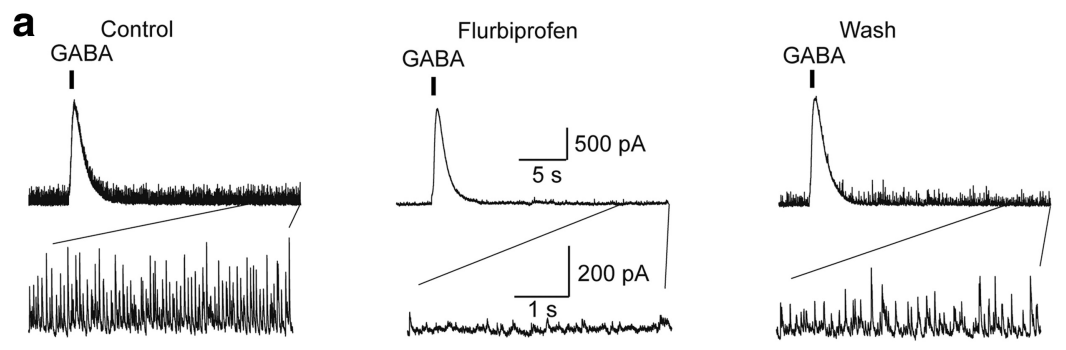

b
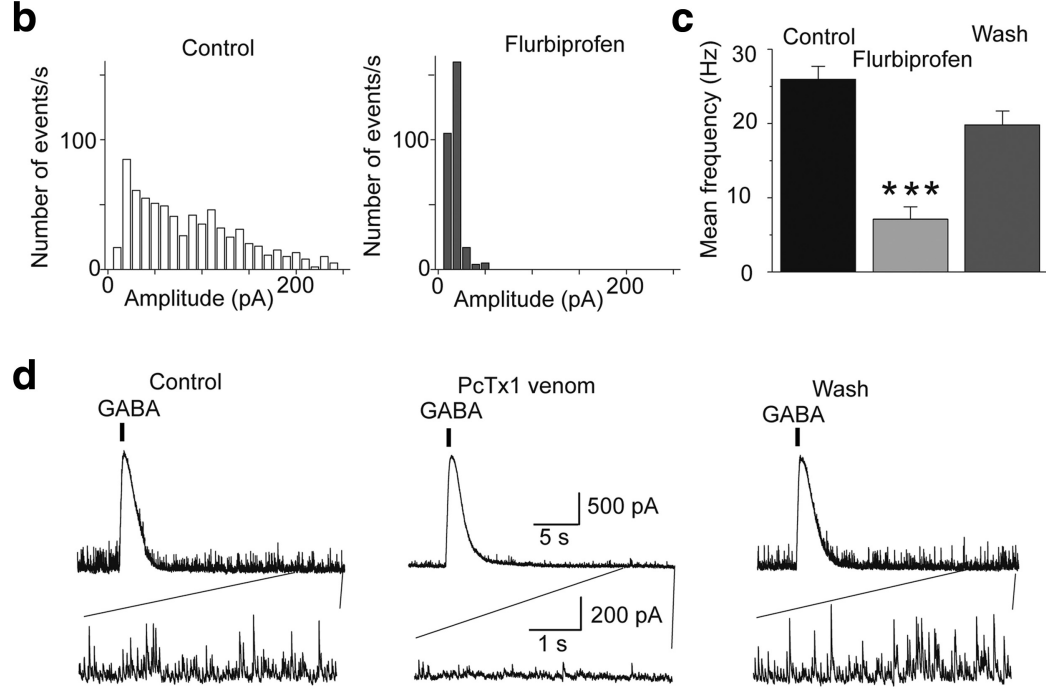

e
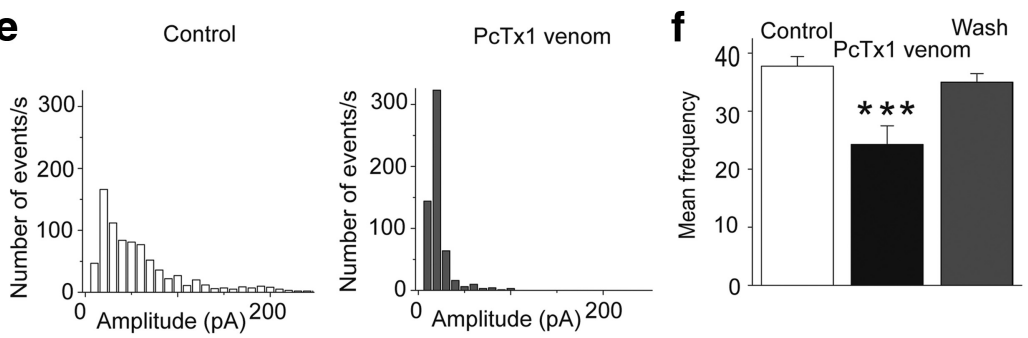

Figure 4. Antagonism of ASIC1a reduces spontaneous inhibitory activity. Recordings were obtained from BLA principal cells in the presence of CNQX (10 $\mu \mathrm{M})$, D-AP5 $(50 \mu \mathrm{M})$, and SCH50911 (10 $\mu \mathrm{M})$, at $V_{\mathrm{h}}=+30 \mathrm{mV}$. $\boldsymbol{a}$, sIPSCs in control medium, in the presence of bath-applied flurbiprofen ( $2 \mathrm{mM})$, and after a 10 min wash. Flurbiprofen suppressed sIPSCs, with no significant effect on the amplitude of $\mathrm{GABA}_{\mathrm{A}}$-mediated currents evoked by pressure-applied GABA (400 $\mu \mathrm{M} G A B A, 200$ ms duration of pressure application). The bottom traces show, in an expanded view, the last 5 s of the upper traces. $\boldsymbol{b}$, Amplitude-frequency histograms for sIPSCs in control medium and in the presence of $2 \mathrm{~mm}$ flurbiprofen, for the cell shown in $\boldsymbol{a}$ (bin size, $10 \mathrm{pA}$ ). $\boldsymbol{c}$, Group data of the frequency of sIPSCs in control medium and in the presence of $2 \mathrm{~mm}$ flurbiprofen $\left(n=7\right.$ neurons from 4 rats, ${ }^{* * *} p<0.001$ when compared with the control). $\boldsymbol{d}$, sIPSCs before, during, and after bath-applied PcTX1 venom (1:1000 dilution of the $100 \mu$ l lyophilized, milked venom). PcTx1 suppressed sIPS(s, with no significant effect on the amplitude of $G A B A_{A}$-mediated currents evoked by pressure-applied GABA. The bottom traces show, in an expanded view, the last $5 s$ of the upper traces. $\boldsymbol{e}$, Amplitude-frequency histograms for sIPSCs in control medium and in the presence of PcTx1, for the cell shown in $\boldsymbol{d}$ (bin size, $10 \mathrm{pA}$ ). $\boldsymbol{f}$, Group data of the frequency of $\mathrm{sIPSC}$ in control medium and in the presence of $\operatorname{PcTx} 1\left(n=4\right.$ neurons from 3 rats; ${ }^{* *} p<0.01$ when compared with the control).

tamatergic spontaneous activity, but the increase of GABAergic activity is significantly greater than the increase of glutamatergic activity.

Next, we examined the effects of ASICla activation on BLA field potentials evoked by stimulation of the external capsule. Due to the nonlaminar architecture of the amygdala, the activity of neuronal populations in this structure does not generate large extracellular electric dipoles, and, therefore, evoked field potentials have small amplitude, and often include both synaptic and spiking activity. We have consistently observed that any pharmacological manipulation that suppresses GABAergic inhibition (e.g., bath application of bicuculline) increases dramatically the evoked field potentials, while the reverse is true (the field potentials are reduced) when inhibition is enhanced (e.g., by bath application of muscimol). When we bathapplied ammonium $(8 \mathrm{~mm})$, the amplitude of the field potentials was reduced to $76.4 \pm 4 \%$ of the control values (from $0.46 \pm 0.02$ to $0.36 \pm 0.01 \mathrm{mV}, n=4, t_{(3)}$ $=6.326, p=0.008$; data not shown). This reduction of the field potentials by ammonium suggested that ASICla activation suppresses excitability in the BLA network. To obtain more clear evidence of such an effect, we first induced epileptiform activity by increasing the concentration of $\mathrm{K}^{+}$in the ACSF to $7 \mathrm{~mm}$ and removing $\mathrm{Mg}^{2+}$, and then applied ammonium. Bath application of $8 \mathrm{~mm}$ ammonium reduced the evoked field potentials and eliminated the spontaneous epileptiform discharges ( $n=5$; Fig. $6 c$ ). The same concentration of ammonium had no significant effect on spontaneous epileptiform activity when flurbiprofen (2 $\mathrm{mm}$ ) was present in the slice medium $(n=4$; data not shown), which is consistent with the involvement of ASIC1a channels in the suppressive effect of ammonium.

\section{The net effect of ASIC1a blockade on BLA excitability}

To determine whether the activity of ASIC1a channels favors enhancement of GABAergic inhibition over that of glutamatergic excitation also in the basal state, we examined the effect of ASICla blockade by flurbiprofen on sIPSCs and sEPSCs recorded simultaneously from principal cells (Fig. 7a). Flurbiprofen decreased the frequency of sIPSCs from $15 \pm 1$ to $5 \pm 1$ $\mathrm{Hz}\left(n=9, t_{(8)}=11.11, p=0.000004\right)$, and the frequency of sEPSCs from $16 \pm 1$ to $11 \pm 1 \mathrm{~Hz}\left(n=9, t_{(8)}=6.4, p=\right.$ $0.0002)$. The reduction in the frequency of sIPSCs $(69 \pm 4 \%)$ was significantly greater than the reduction in the frequency of sEPSCs $(30 \pm 4 \% ; p=$ $0.000002)$. We also tested the effects of flurbiprofen on evoked field potentials, in normal ACSF. Bath application of $2 \mathrm{~mm}$ flurbiprofen increased the amplitude of the field potentials from $0.61 \pm 0.09$ to $1.05 \pm 0.19 \mathrm{mV}\left(n=5, t_{(4)}\right.$ $=3.75, p=0.020$; Fig. $7 b$ ). These results suggest that in the basal state the activity of ASIC1a in the BLA favors enhancement of inhibition over excitation.

\section{Effects of ASIC1a activation or blockade on anxiety- like behavior}

Since the net role of ASIC1a in the BLA is primarily to enhance inhibition, activation of these channels could have an anxiolytic effect. One test of anxiety-like behavior in rodents is the open field, where the more anxious the animal is, the less time it spends in the center of the field. Microinjection of ammonium (12 
a pH 6.65

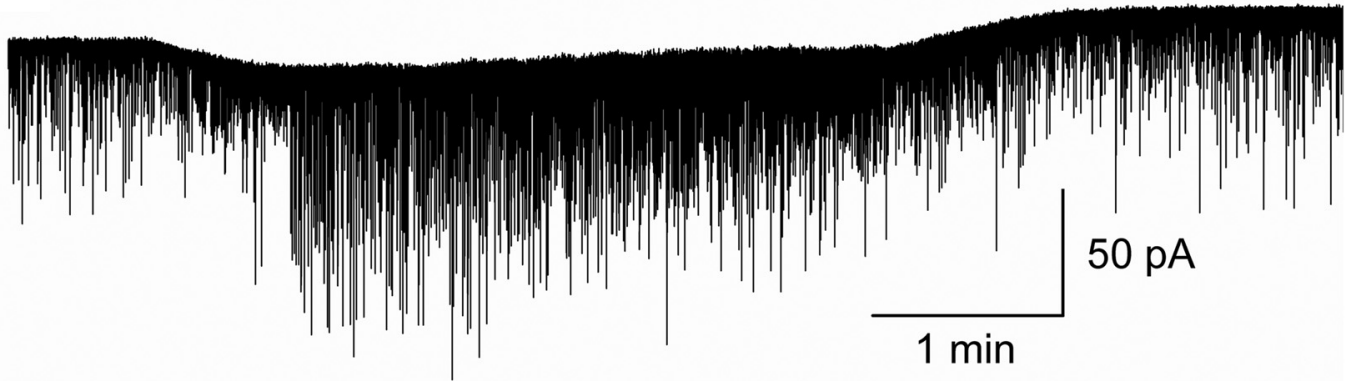

Wash

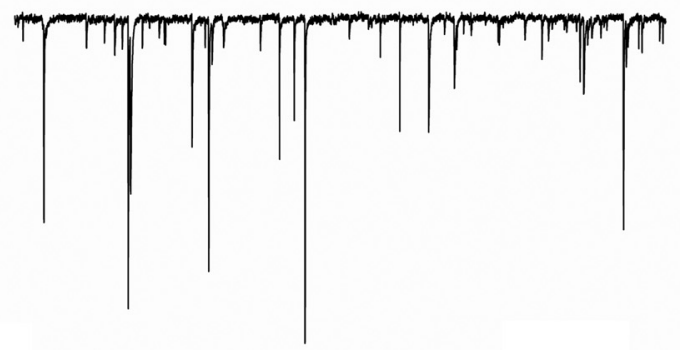

CNQX

b

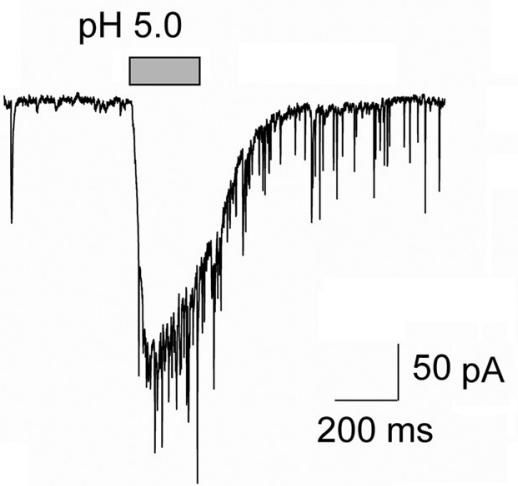

C

Ammonium

$1 \mathrm{~s}$

d

Flurbiprofen

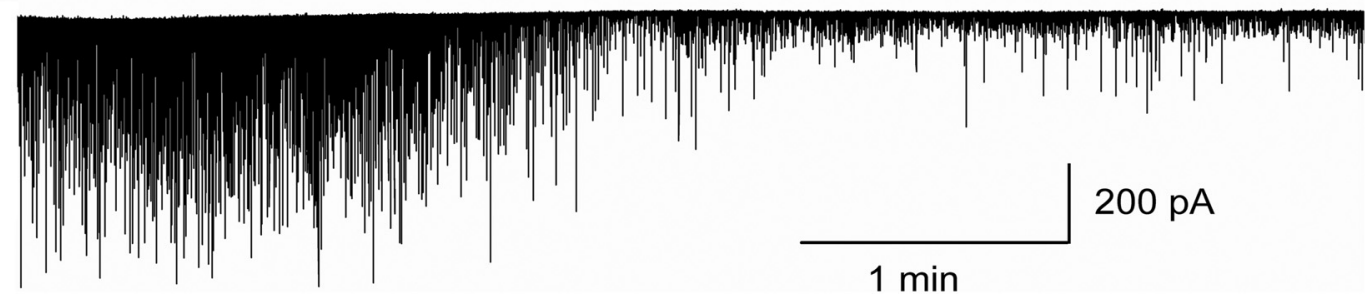

Figure 5. Activation of ASIC1a increases the excitatory drive of interneurons. Recordings are from interneurons at $V_{\mathrm{h}}-58 \mathrm{mV}$ and in the presence of $\mathrm{D}-\mathrm{AP5}$ ( $50 \mu \mathrm{m}$ ) and SCH50911 (10 $\left.\mu \mathrm{m}\right)$. $\boldsymbol{a}$, Lowering the $\mathrm{pH}$ of the bath increased the frequency of sEPSCs. The bottom current traces in $a$ are from the same cell as in the top trace, at an expanded view. Bath-applied CNQX (10 $\mu \mathrm{m}$ ) blocked the recorded currents. $\boldsymbol{b}$, Currents evoked by pressure application ( $200 \mathrm{~ms}$ ) of acidified ACSF in the absence of CNQX, displayed "riding" EPSCs. $\boldsymbol{c}$, Pressure application of ammonium ( 40 mm, 500 ms duration) increased the frequency of sEPSCs. $\boldsymbol{d}$, Bath application of flurbiprofen (1 mM) decreased the frequency of sEPSCS.

mmol) bilaterally into the BLA significantly increased the time the rats spent in the center of the open field, from $10.14 \pm 1.7 \%$ of the total movement time (after vehicle microinjection) to $18.9 \pm$ $2.0 \%$ of the total movement time $\left(t_{(9)}=4.618, p=0.001, n=10\right.$; Fig. $8 c$ ). We also examined the effects of blockade of ASIC1a on anxiety. The effects of the synthetic psalmotoxin (400 nmol; $n=$ 9) and the tarantula venom psalmotoxin ( $1 \mu \mathrm{l}$ from a $1 / 1000$ dilution of the $100 \mu$ l lyophilized milked venom; $n=4$ ) were similar, therefore the results were combined. Psalmotoxin significantly reduced the time the rats spent in the center of the open field, from $12.9 \pm 1.1 \%$ of the total movement time (after vehicle microinjection) to $7.9 \pm 1.0 \%$ of the total movement time $(p=$ $0.005, n=13$; Fig. $8 d$ ). The distance the rats traveled in the open field was not significantly affected by activation or blockade of ASIC1a. Thus, activation of ASIC1a by ammonium $(12 \mathrm{mmol})$ increased the distance traveled from $1863.9 \pm 143.7 \mathrm{~cm}$ (after vehicle injection) to $1939.7 \pm 156.6 \mathrm{~cm}\left(t_{(9)}=0.367, p=0.722\right)$. Blockade of ASIC1a by psalmotoxin increased the distance traveled from $2311.6 \pm 228.9 \mathrm{~cm}$ (vehicle) to $2366.2 \pm 196.2$ $\mathrm{cm}\left(t_{(12)}=0.358, p=0.727\right)$. 
a
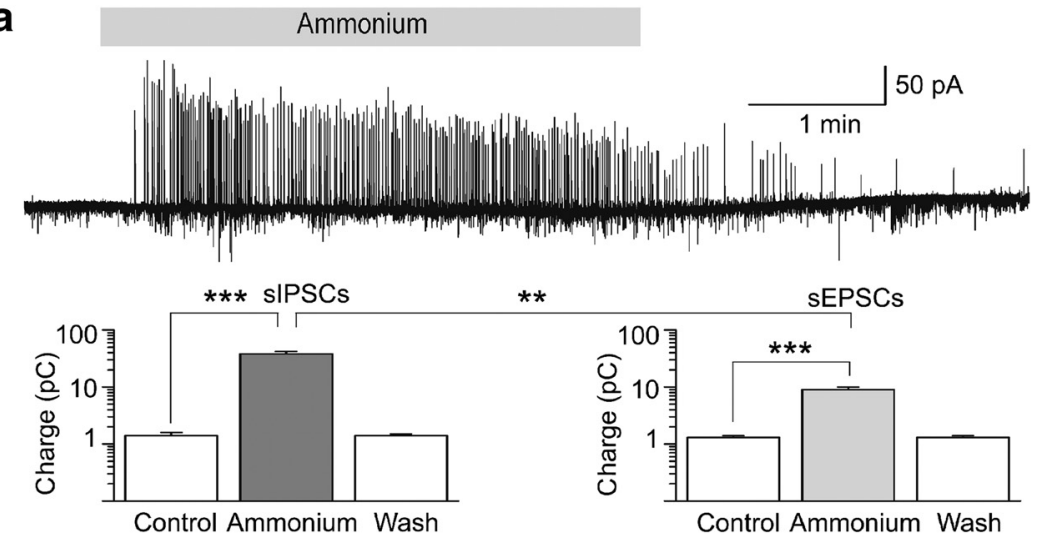

b
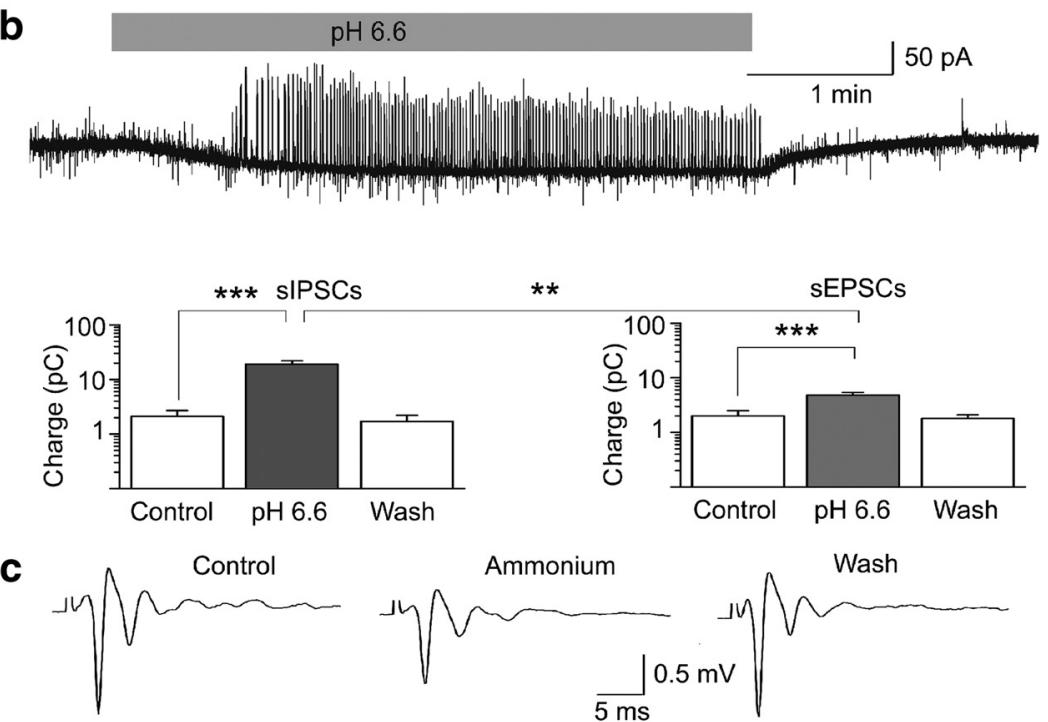

$* *$

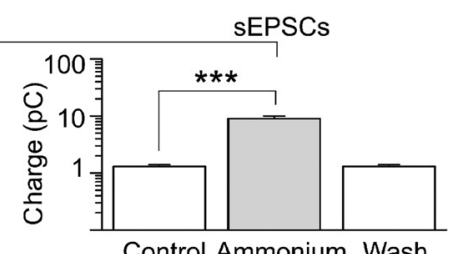

Control Ammonium Wash
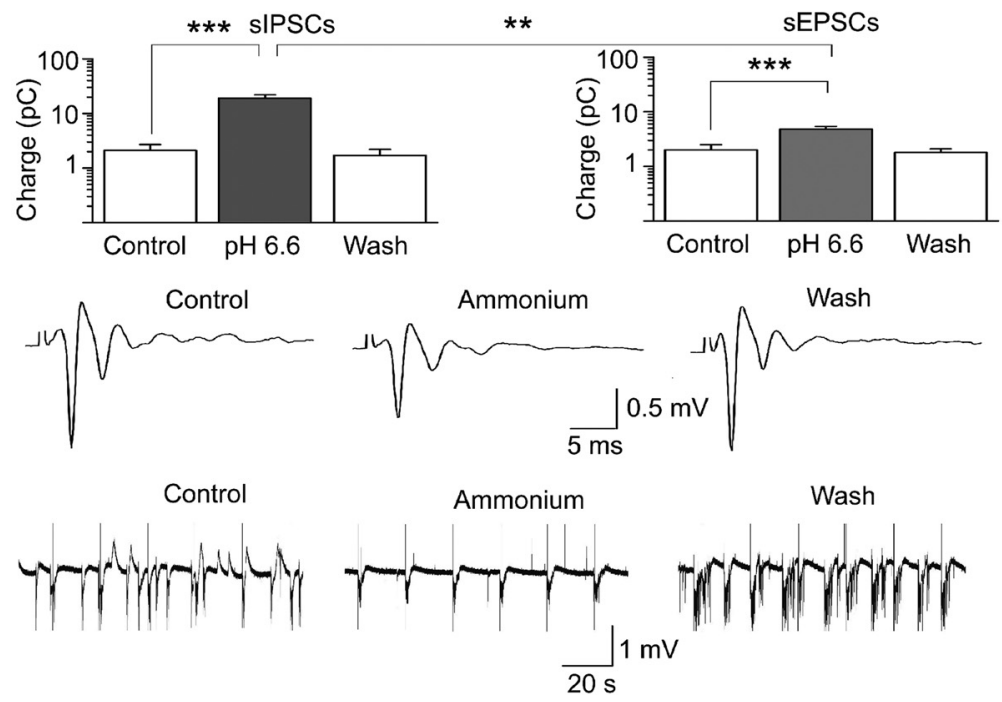

Figure 6. The net effect of ASIC1 a activation is suppression of BLA excitability. $\boldsymbol{a}, \boldsymbol{b}$, Simultaneous recordings of sIPSCs (outward currents) and sEPSCs (inward currents) were obtained from principal cells at $V_{\mathrm{h}}-58 \mathrm{mV}$, and in the presence of D-AP5 $(50 \mu \mathrm{M})$ and SCH50911 (10 $\mu \mathrm{M})$. Bath application of 5 mM ammonium (a) or acidified solution $(\boldsymbol{b})$ increased the charge transferred by sIPSCs and SEPSCS; the increase in the charge transferred by SIPSCS was significantly greater than the increase in charge transferred by sEPSCS. Example traces are shown in the top of $\boldsymbol{a}$ and $\boldsymbol{b}$, and group data are shown in the bar graphs; $n=21$ neurons from seven rats in $\boldsymbol{a}$, and $n=9$ neurons from four rats in $\boldsymbol{b}^{* * *} p<0.001$ for the comparisons between control and ammonium, or control and pH 6.6; ${ }^{* *} p<0.01$ for the comparisons between percentage increase in charge transferred by sIPSCs versus percentage increase in charge transferred by sEPSCS. c, Field potentials evoked in the BLA by single-pulse stimulation of the external capsule (top traces), and spontaneous field activity recorded in gap-free mode (bottom traces). Recordings are in medium containing $7 \mathrm{~mm} \mathrm{~K}^{+}$and zero $\mathrm{Mg}^{2+}$, which induced epileptiform activity. Bath application of $8 \mathrm{~mm}$ ammonium reduced the evoked field potentials and blocked epileptiform discharges. Each of the three field potentials shown in the top is an average of 10 sweeps; the stimulus artifacts have been truncated for clarity. The equidistant vertical lines in the traces of spontaneous activity are stimulus artifacts, as evoked field potentials were sampled during gap-free recordings, by stimulation applied every $20 \mathrm{~s}$.

Another behavioral test that can assess the level of anxiety is the light/dark box. In this test, the less anxious the animal is, the longer the latency to enter the dark compartment and the longer the time it spends in the light compartment. Rats that received microinjection of ammonium ( $12 \mathrm{mmol}$ ) bilaterally into the BLA displayed a longer latency (127 $\pm 22.3 \mathrm{~s}, n=9)$ to enter the dark compartment-after placed in the light compartment-compared with rats that received the vehicle $\left(29.01 \pm 7.4 \mathrm{~s}, n=9, t_{(16)}\right.$ $=4.2, p=0.0007$; Fig. $8 e$ ). In addition, the time spent in the light compartment was significantly longer in rats administered ammonium (154.9 \pm 17.9 s) compared with vehiclemicroinjected rats $(43.6 \pm 7.8 \mathrm{~s}$, $t_{(16)}=5.7, p=0.00003$; Fig. 8f).

\section{Discussion}

In the present study, we demonstrated that in the rat BLA, ASICla channels are present on both interneurons and principal cells, and their activation by ammonium, or by lowering extracellular $\mathrm{pH}$, increases glutamatergic and GABAergic activity in the network. However, the increase in GABAergic activity predominates (Fig. $6 a, b$ ), suppressing overall excitability. Accordingly, ammonium blocked epileptiform discharges in vitro (Fig. 6c), and reduced anxiety-like behavior when microinjected bilaterally into the BLA in vivo (Fig. 8c,e,f). We also found that ASICla channels are active in the basal state, enhancing primarily GABAergic inhibition (Figs. 4,7 ) by direct depolarization of interneurons, but also by indirect excitation of interneurons secondary to ASICla-mediated depolarization of principal cells (Fig. 5d). Accordingly, in vivo blockade of ASICla in the BLA increased anxiety (Fig. 8d).

Native ASICla channels appear to be homomeric trimers, but they may also be heteromeric trimers combining with the ASIC2a or ASIC2b subunits (Baron et al., 2002; Sherwood et al., 2011), which are splice variants of the ASIC2. The BLA displays a markedly high expression of the ASIC1a subunit (Wemmie et al., 2003; Coryell et al., 2007), but it also expresses the ASIC2a and ASIC2b subunits (Lingueglia et al., 1997; Biagini et al., 2001). It is unknown if the functional ASICla channels in the BLA are homomeric ASICla trimers, or if they coassemble with the ASIC2a or ASIC2b. From the two mechanisms that we used to activate these channels, the low $\mathrm{pH}$ can activate any type of ASIC, while ammonium specifically activates ASICla currents as demonstrated in isolated sensory neurons (Pidoplichko, 1992), as well as in central dopaminergic neurons, hippocampal interneurons, and HEK 293 cells (Pidoplichko and Dani, 2006). The effects we observed when ASICs were activated by either low $\mathrm{pH}$ or ammonium application was blocked by flurbiprofen, and both flurbiprofen and PcTX1 significantly reduced the frequency of sIPSCs in the BLA. Flurbiprofen has been shown to inhibit PcTX1-sensitive currents (Voilley et al., 2001), and PcTX1 specifically blocks currents mediated by homomeric ASICla (Escoubas et al., 2000; Baron et al., 2002). Therefore, at least a portion of the ASICla channels in the BLA are probably homomeric trimers.

If we consider that, in the BLA, activation of ASIC1a depolarizes both interneurons and principal neurons, but also that in- 
terneurons constitute only a small percentage of the total neuronal population in the BLA (McDonald and Mascagni, 2002; Sah et al., 2003), the question arises as to why the increase of GABAergic inhibition predominates. A possible explanation lies on the evidence that much of the excitatory input within the BLA circuitry is directed onto interneurons, while most of the inhibitory input is directed onto principal cells (Lang and Paré, 1997; Smith et al., 1998; Pan et al., 2009; Popescu and Paré, 2011). In accordance with these findings, we have observed sIPSCs in only a small percentage of the interneurons we have recorded from, while all interneurons display high activity of single sEPSCs and, occasionally, bursts of sEPSCs; in contrast, many principal cells display "bursts" of sIPSCs. Therefore, when principal neurons depolarize upon ASIC1a activation and glutamate is released, the resulting increased excitation is directed primarily onto interneurons; at the same time, the increase of GABA release due to depolarization of interneurons upon ASIC1a activation is directed primarily onto principal neurons. Thus, the net effect is inhibitory. The inhibitory strength in the BLA network may also be enhanced by the electrical coupling among BLA interneurons (Muller et al., 2005; Woodruff and Sah, 2007).

Both the electrophysiological and the behavioral results suggested that the ASIC1a channels in the BLA are active in the basal state, preferentially increasing background inhibition. Thus, flurbiprofen, or PcTX1 reversibly decreased the frequency and amplitude of pharmacologically isolated sIPSCs, and when sIPSCs and sEPSCs were recorded simultaneously, flurbiprofen preferentially reduced the sIPSCs. In addition, flurbiprofen reduced the basal excitatory drive of interneurons. These results are consistent with the increase of the evoked population response in the BLA by bath application of flurbiprofen (increased population spiking due to reduced inhibition), as well as with the increase in anxiety-like behavior in the open field, when psalmotoxin was injected bilaterally in the BLA. The occurrence of transient $\mathrm{pH}$ shifts in the basal state that can activate ASIC1a is not surprising. The content of synaptic vesicles is acidic (Miesenböck et al., 1998), and ASIC1a channels are located on somatodendritic regions and postsynaptic sites (Zha et al., 2006). Therefore, local pH shifts in the synaptic cleft during spontaneous synaptic transmission could activate ASIC1a. Furthermore, measurements of interstitial $\mathrm{pH}$ have shown fluctuations during normal synaptic activity, and the nature of these fluctuations (alkalinization or acidification, and their time course relative to the intensity of synaptic activity) may differ in different brain regions (Xiong and Stringer, 2000; Chesler, 2003). The present data suggest that in the rat BLA, $\mathrm{pH}$ shifts induced by spontaneous synaptic transmission onto interneurons and/or other mechanisms, activate ASIC1a, contributing to interneuronal depolarization and increase in tonic inhibitory activity. This finding may provide a molecular explanation for the association of hypocapnia and alkalosis with panic attacks. Loss of the basal activity of ASICla channels may be the mechanism underlying the panic attacks experienced by patients when resting $\mathrm{pCO}_{2}$ is low (which brings about alkalosis), while the alleviation of panic symptoms after treatment that brings pCO2 and pH back to normal levels (Salkovskis et al., 1986; Meuret and Ritz, 2010) may relate to restoration of the basal ASIC1a activity in the BLA.

The anxiolytic function of ASIC1a, as suggested by the present results, contradicts previous studies showing that activation of ASICla, in mice, is necessary for the generation and expression of certain types of fear, and genetic elimination of these channels has anxiolytic effects (Coryell et al., 2007; Dwyer et al., 2009; Ziemann et al. 2009). The discrepancy cannot be attributed to possible developmental alterations in the ASIC1a-null mice, as most of the results obtained in these mice were confirmed by intraventricular administration of ASIC1a antagonists in wild-type mice (Coryell et al., 2007; Dwyer et al., 2009; Ziemann et al. 2009). In the present study, we activated or inhibited ASIC1a by local injections into the BLA, which is a different situation from lacking ASIC1a or inhibiting ASIC1a throughout the brain. It could be argued, therefore, that in the mice studies, the anxiogenic func- 
a

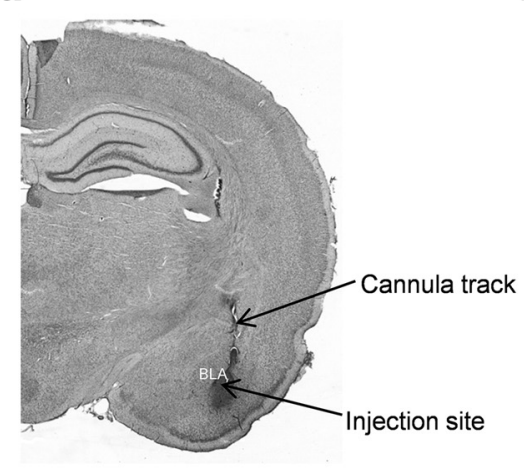

b

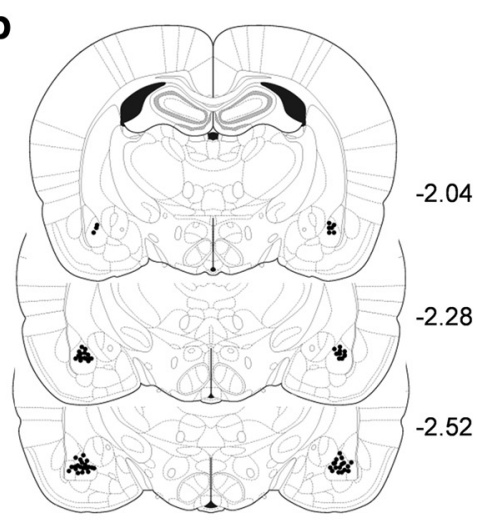

Open Field

C
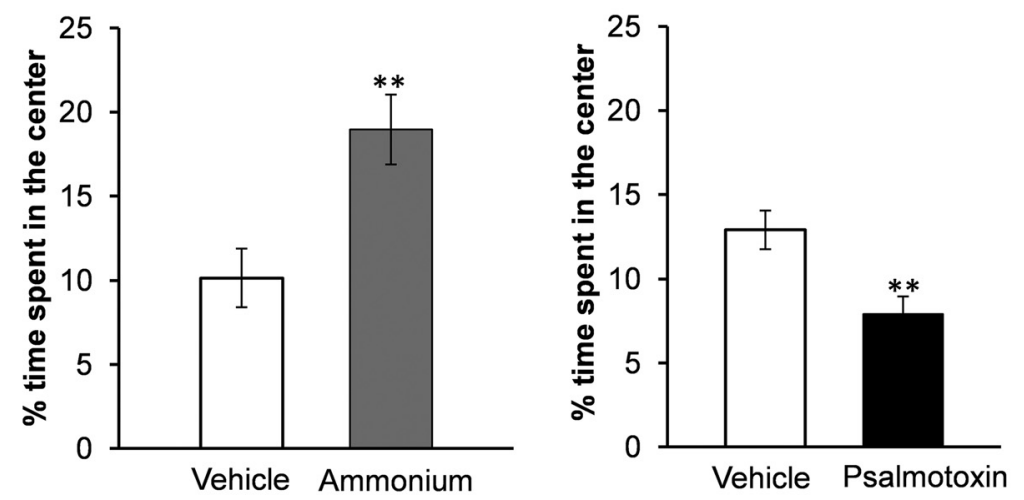

\section{Light-Dark Box}

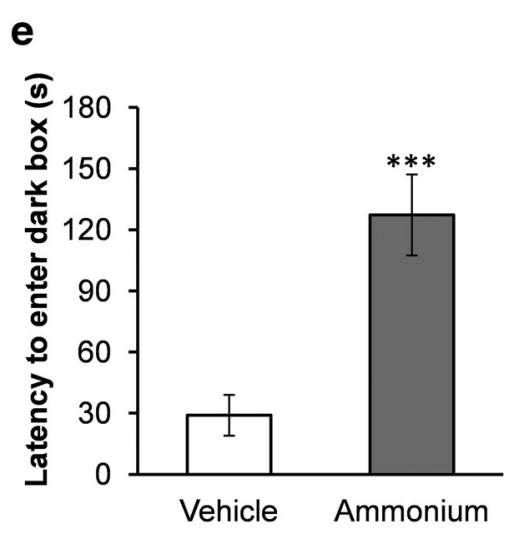

f

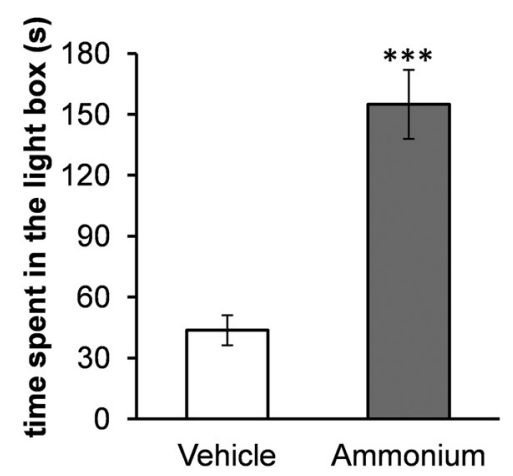

Figure 8. In vivo activation of ASIC1a in the BLA suppresses anxiety-like behavior, while antagonism of ASIC1a increases anxiety. $\boldsymbol{a}$, Panoramic photomicrograph of a coronal, Nissl-stained brain section, showing the drug injection site. Methylene blue was injected before histological analysis. $\boldsymbol{b}$, Schematic representation of coronal sections from rat brain (from Paxinos and Watson, 2005) showing the injection sites. Coordinates are with respect to bregma. The "dots" (small filled circles) represent the locations of the tips of the guide cannulae, as revealed by histological analysis; their number is fewer than the total number of rats used because of several overlaps. $\boldsymbol{c}, \boldsymbol{d}$, In the open field test, the rats spent significantly more time in the center, after microinjection of ammonium bilaterally into the BLA (c), and significantly less time in the center, after microinjection of psalmotoxin into the BLA (d) , compared with the time they spent in the center of the open field when injected with the vehicle.e, $\boldsymbol{f}$, In the light/dark box test, rats microinjected with ammonium bilaterally into the BLA took a significantly longer time to enter the dark compartment (e), and spent more total time in the light compartment $(\boldsymbol{f})$, compared with rats injected with the vehicle; ${ }^{* *} p<0.01,{ }^{* * *} p<0.001$.

tion of ASICla was due to involvement of regions other than the BLA. A similar argument can be made if we consider that different behavioral tests of anxiety may differentially engage parts of the fear circuitry. However, the open field test was used in both the present study and the mice studies (Coryell et al., 2007).
Furthermore, the deficit in the fear elicited by $\mathrm{CO}_{2}$ inhalation in ASIC1a-null mice was rectified by localized ASIC1a expression in the BLA (Ziemann et al., 2009), suggesting that ASIC1a in the mouse BLA is necessary to hyperexcite the amygdala and generate the fear response. Thus, the "systemic" approach in the mice studies versus the BLA-focused approach in the present study does not seem to explain the discrepancy of the results. It is possible, therefore, that there is species difference in the function of ASIC1a, at least in the BLA. Such species difference exists for the function of the GluK1 receptors in the BLA, the blockade of which is anxiogenic in mice (Wu et al., 2007), but anxiolytic in rats (Aroniadou-Anderjaska et al., 2012); given this precedent, it would not be surprising if mice and rats also differ in other parameters regulating BLA excitability, including the role of ASIC1a. It is also possible that only certain strains of mice differ substantially from rats, as there are marked differences between mouse strains in GABA function in the BLA and in anxiety-like behaviors (Griebel et al., 2000; DuBois et al., 2006). To obtain some preliminary information as to whether species differences could have contributed to the conflicting results, we recorded from a few neurons in BLA slices from C57BL/6 mice (the same strain as the one used in the mice studies cited above). Although ASIC1a activation increased sIPSCs in the BLA of these mice, some neurons did not respond. In addition, we also encountered principal cells, which responded to ammonium with more bursts of sEPSCs than sIPSCs. Notably, basal GABAergic activity was clearly lower than in the rat BLA. Detailed studies would be needed to characterize these differences between mouse and rat BLA.

Even though species differences may have contributed to the contradictory results regarding the role of ASICla in anxiety, the similarities between the studies in mice and the present study deserve attention. Thus, activation of ASIC1a in C57BL/6 mice suppresses seizures in vivo, and blocks hippocampal epileptiform activity in vitro, an effect that was attributed to ASIC1a-mediated increase of GABAergic inhibitory activity (Ziemann et al., 2008); these data are consistent with our findings in rat BLA slices, where bath application of ammonium suppressed epileptiform activity. Therefore, even in the brain of C57BL/6 mice, ASIC1a activation increases inhibition. The behavioral results on anxiety (Coryell et al., 2007; Dwyer et al., 2009; Ziemann et al. 2009) may indicate that the function of these channels is not the same in all brain regions, and that in the BLA of the C57BL/6 
mice, ASIC1a activation promotes hyperactivity. Other factors that can contribute to discrepancies in studies of ASIC1a function are the strength, duration, and temporal pattern of ASIC1a activation. In our studies, the acidification produced by either application of ammonium or acidified ACSF can be considered acute and mild. Strong, slow, or prolonged acidification can lead to desensitization of ASIC1a (Bolshakov et al., 2002; Gründer and Chen, 2010), which may give way to other mechanisms that produce hyperexcitability.

Together, the data presented here demonstrate that in the rat amygdala, the primary function of ASICla channels is to increase inhibition, and, as a result, activation of these channels has anxiolytic effects. However, we are still at the early stages of understanding the roles that ASICla channels play in the excitability of different brain regions, the parameters that affect these roles, and whether there are species differences. Delineating the functions of these channels can potentially have profound implications for the treatment of several neurological and mental illnesses. The anticonvulsant effect of mild acidosis by inhalation of $5 \% \mathrm{CO}_{2}$ has already been demonstrated in humans (Tolner et al., 2011), and it seems reasonable to propose that similar anticonvulsant effects could be achieved by mild hyperammonemia, provided that a safe means of inducing a mild hyperammonemic state is developed. Research aimed at discovering positive ASICla modulators (Askwith et al., 2000; Cho and Askwith, 2007; Sherwood and Askwith, 2009) may hold great promise not only for the prevention and treatment of seizures, but also for the treatment of psychiatric disorders in which hyperexcitability of the BLA plays a central role.

\section{References}

Aroniadou-Anderjaska V, Qashu F, Braga MF (2007) Mechanisms regulating GABAergic inhibitory transmission in the basolateral amygdala: implications for epilepsy and anxiety disorders. Amino Acids 32:305-315. CrossRef Medline

Aroniadou-Anderjaska V, Pidoplichko VI, Figueiredo TH, Almeida-Suhett CP, Prager EM, Braga MF (2012) Presynaptic facilitation of glutamate release in the basolateral amygdala: a mechanism for the anxiogenic and seizurogenic function of GluK1 receptors. Neuroscience 221:157-169. CrossRef Medline

Askwith CC, Cheng C, Ikuma M, Benson C, Price MP, Welsh MJ (2000) Neuropeptide FF and FMRFamide potentiate acid-evoked currents from sensory neurons and proton-gated DEG/ENaC channels. Neuron 26:133141. CrossRef Medline

Askwith CC, Benson CJ, Welsh MJ, Snyder PM (2001) DEG/ENaC ion channels involved in sensory transduction are modulated by cold temperature. Proc Natl Acad Sci U S A 98:6459-6463. CrossRef Medline

Baron A, Waldmann R, Lazdunski M (2002) ASIC-like, proton-activated currents in rat hippocampal neurons. J Physiol 539:485-494. CrossRef Medline

Biagini G, Babinski K, Avoli M, Marcinkiewicz M, Séguéla P (2001) Regional and subunit-specific downregulation of acid-sensing ion channels in the pilocarpine model of epilepsy. Neurobiol Dis 8:45-58. CrossRef Medline

Bolshakov KV, Essin KV, Buldakova SL, Dorofeeva NA, Skatchkov SN, Eaton MJ, Tikhonov DB, Magazanik LG (2002) Characterization of acidsensitive ion channels in freshly isolated rat brain neurons. Neuroscience 110:723-730. CrossRef Medline

Braga MF, Aroniadou-Anderjaska V, Manion ST, Hough CJ, Li H (2004) Stress impairs alpha(1A) adrenoceptor-mediated noradrenergic facilitation of GABAergic transmission in the basolateral amygdala. Neuropsychopharmacology 29:45-58. CrossRef Medline

Chen CC, England S, Akopian AN, Wood JN (1998) A sensory neuronspecific, proton-gated ion channel. Proc Natl Acad Sci U S A 95:1024010245. CrossRef Medline

Chesler M (2003) Regulation and modulation of pH in the brain. Physiol Rev 83:1183-1221. Medline

Cho JH, Askwith CC (2007) Potentiation of acid-sensing ion channels by sulfhydryl compounds. Am J Physiol Cell Physiol 292:C2161-2174. CrossRef Medline

Coryell MW, Ziemann AE, Westmoreland PJ, Haenfler JM, Kurjakovic Z, Zha XM, Price M, Schnizler MK, Wemmie JA (2007) Targeting ASICla reduces innate fear and alters neuronal activity in the fear circuit. Biol Psychiatry 62:1140-1148. CrossRef Medline

Coryell MW, Wunsch AM, Haenfler JM, Allen JE, Schnizler M, Ziemann AE, Cook MN, Dunning JP, Price MP, Rainier JD, Liu Z, Light AR, Langbehn DR, Wemmie JA (2009) Acid-sensing ion channel-1a in the amygdala, a novel therapeutic target in depression-related behavior. J Neurosci 29: 5381-5388. CrossRef Medline

Diochot S, Salinas M, Baron A, Escoubas P, Lazdunski M (2007) Peptides inhibitors of acid-sensing ion channels. Toxicon 49:271-284. CrossRef Medline

DuBois DW, Perlegas A, Floyd DW, Weiner JL, McCool BA (2006) Distinct functional characteristics of the lateral/basolateral amygdala GABAergic system in C57BL/6J and DBA/2J mice. J Pharmacol Exp Ther 318:629_ 640. CrossRef Medline

Dwyer JM, Rizzo SJ, Neal SJ, Lin Q, Jow F, Arias RL, Rosenzweig-Lipson S, Dunlop J, Beyer CE (2009) Acid sensing ion channel (ASIC) inhibitors exhibit anxiolytic-like activity in preclinical pharmacological models. Psychopharmacology 203:41-52. CrossRef Medline

Escoubas P, De Weille JR, Lecoq A, Diochot S, Waldmann R, Champigny G, Moinier D, Ménez A, Lazdunski M (2000) Isolation of a tarantula toxin specific for a class of proton-gated $\mathrm{Na}+$ channels. J Biol Chem 275: 25116-25121. CrossRef Medline

Etkin A, Wager TD (2007) Functional neuroimaging of anxiety: a metaanalysis of emotional processing in PTSD, social anxiety disorder, and specific phobia. Am J Psychiatry 164:1476-1488. CrossRef Medline

Gale GD, Anagnostaras SG, Godsil BP, Mitchell S, Nozawa T, Sage JR, Wiltgen B, Fanselow MS (2004) Role of the basolateral amygdala in the storage of fear memories across the adult lifetime of rats. J Neurosci 24:3810-3815. CrossRef Medline

Gonzalez LE, Andrews N, File SE (1996) 5-HT1A and benzodiazepine receptors in the basolateral amygdala modulate anxiety in the social interaction test, but not in the elevated plus-maze. Brain Res 732:145-153. CrossRef Medline

Griebel G, Belzung C, Perrault G, Sanger DJ (2000) Differences in anxietyrelated behaviours and in sensitivity to diazepam in inbred and outbred strains of mice. Psychopharmacology 148:164-170. CrossRef Medline

Gründer S, Chen X (2010) Structure, function, and pharmacology of acidsensing ion channels (ASICs): focus on ASICla. Int J Physiol Pathophysiol Pharmacol 2:73-94. Medline

Krishtal OA, Pidoplichko VI (1980) A receptor for protons in the nerve cell membrane. Neuroscience 5:2325-2327. CrossRef Medline

Lang EJ, Paré D (1997) Similar inhibitory processes dominate the responses of cat lateral amygdaloid projection neurons to their various afferents. J Neurophysiol 77:341-352. Medline

Lingueglia E, de Weille JR, Bassilana F, Heurteaux C, Sakai H, Waldmann R, Lazdunski M (1997) A modulatory subunit of acid sensing ion channels in brain and dorsal root ganglion cells. J Biol Chem 272:29778-29783. CrossRef Medline

McDonald AJ, Mascagni F (2002) Immunohistochemical characterization of somatostatin containing interneurons in the rat basolateral amygdala. Brain Res 943:237-244. CrossRef Medline

Meuret AE, Ritz T (2010) Hyperventilation in panic disorder and asthma: empirical evidence and clinical strategies. Int J Psychophysiol 78:68-79. CrossRef Medline

Miesenböck G, De Angelis DA, Rothman JE (1998) Visualizing secretion and synaptic transmission with $\mathrm{pH}$-sensitive green fluorescent proteins. Nature 394:192-195. CrossRef Medline

Muller JF, Mascagni F, McDonald AJ (2005) Coupled networks of parvalbumin-immunoreactive interneurons in the rat basolateral amygdala. J Neurosci 25:7366-7376. CrossRef Medline

Pan BX, Dong Y, Ito W, Yanagawa Y, Shigemoto R, Morozov A (2009) Selective gating of glutamatergic inputs to excitatory neurons of amygdala by presynaptic GABAb receptor. Neuron 61:917-929. CrossRef Medline

Park K, Lee S, Kang SJ, Choi S, Shin KS (2007) Hyperpolarization-activated currents control the excitability of principal neurons in the basolateral amygdala. Biochem Biophys Res Commun 361:718-724. CrossRef Medline 
Paxinos G, Watson C (2005) The rat brain in stereotaxic coordinates, fourth edition. New York: Elsevier.

Phelps EA, LeDoux JE (2005) Contributions of the amygdala to emotion processing: from animal models to human behavior. Neuron 48:175-187. CrossRef Medline

Pidoplichko VI (1992) Ammonia and proton gated channel populations in trigeminal ganglion neurons. Gen Physiol Biophys 11:39-48. Medline

Pidoplichko VI, Dani JA (2005) Applying small quantities of multiple compounds to defined locations of in vitro brain slices. J Neurosci Methods 142:55-66. CrossRef Medline

Pidoplichko VI, Dani JA (2006) Acid-sensitive ionic channels in midbrain dopamine neurons are sensitive to ammonium, which may contribute to hyperammonemia damage. Proc Natl Acad Sci U S A 103:11376-11380. CrossRef Medline

Popescu AT, Paré D (2011) Synaptic interactions underlying synchronized inhibition in the basal amygdala: evidence for existence of two types of projection cells. J Neurophysiol 105:687-696. CrossRef Medline

Rauch SL, Whalen PJ, Shin LM, McInerney SC, Macklin ML, Lasko NB, Orr SP, Pitman RK (2000) Exaggerated amygdala response to masked facial stimuli in posttraumatic stress disorder: a functional MRI study. Biol Psychiatry 47:769-776. CrossRef Medline

Sah P, Faber ES, Lopez De Armentia M, Power J (2003) The amygdaloid complex: anatomy and physiology. Physiol Rev 83:803-834. Medline

Sajdyk TJ, Shekhar A (1997) Excitatory amino acid receptors in the basolateral amygdala regulate anxiety responses in the social interaction test. Brain Res 764:262-264. CrossRef Medline

Salkovskis PM, Jones DR, Clark DM (1986) Respiratory control in the treatment of panic attacks: replication and extension with concurrent measurement of behaviour and pCO2. Br J Psychiatry 148:526-532. CrossRef Medline

Shekhar A, Sajdyk TJ, Gehlert DR, Rainnie DG (2003) The amygdala, panic disorder, and cardiovascular responses. Ann N Y Acad Sci 985:308-325. Medline

Sherwood TW, Askwith CC (2009) Dynorphin opioid peptides enhance acid-sensing ion channel 1a activity and acidosis-induced neuronal death. J Neurosci 29:14371-14380. CrossRef Medline

Sherwood TW, Lee KG, Gormley MG, Askwith CC (2011) Heteromeric acid-sensing ion channels (ASICs) composed of ASIC2b and ASIC1a display novel channel properties and contribute to acidosis-induced neuronal death. J Neurosci 31:9723-9734. CrossRef Medline

Smith Y, Pare JF, Paré D (1998) Cat intraamygdaloid inhibitory network: ultrastructural organization of parvalbumin-immunoreactive elements. J Comp Neurol 391:164-179. CrossRef Medline

Sosulina L, Graebenitz S, Pape HC (2010) GABAergic interneurons in the mouse lateral amygdala: a classification study. J Neurophysiol 104:617626. CrossRef Medline

Stein MB, Stein DJ (2008) Social anxiety disorder. Lancet 371:1115-1125. CrossRef Medline

Tolner EA, Hochman DW, Hassinen P, Otáhal J, Gaily E, Haglund MM, Kubova H, Schuchmann S, Vanhatalo S, Kaila K (2011) Five percent $\mathrm{CO}(2)$ is a potent, fast-acting inhalation anticonvulsant. Epilepsia 52: 104-114. CrossRef Medline

Ugawa S, Ishida Y, Ueda T, Inoue K, Nagao M, Shimada S (2007) Nafamo- stat mesilate reversibly blocks acid-sensing ion channel currents. Biochem Biophys Res Commun 363:203-208. CrossRef Medline

Vazdarjanova A, Cahill L, McGaugh JL (2001) Disrupting basolateral amygdala function impairs unconditioned freezing and avoidance in rats. Eur J Neurosci 14:709-718. CrossRef Medline

Voilley N, de Weille J, Mamet J, Lazdunski M (2001) Nonsteroid antiinflammatory drugs inhibit both the activity and the inflammationinduced expression of acid-sensing ion channels in nociceptors. J Neurosci 21:8026-8033. Medline

Waldmann R, Lazdunski M (1998) H(+)-gated cation channels: neuronal acid sensors in the NaC/DEG family of ion channels. Curr Opin Neurobiol 8:418-424. CrossRef Medline

Waldmann R, Champigny G, Bassilana F, Heurteaux C, Lazdunski M (1997) A proton-gated cation channel involved in acid-sensing. Nature 386:173177. CrossRef Medline

Wang DV, Wang F, Liu J, Zhang L, Wang Z, Lin L (2011) Neurons in the amygdala with response-selectivity for anxiety in two ethologically based tests. PLoS One 6:e18739. CrossRef Medline

Wemmie JA, Askwith CC, Lamani E, Cassell MD, Freeman JH Jr, Welsh MJ (2003) Acid-sensing ion channel 1 is localized in brain regions with high synaptic density and contributes to fear conditioning. J Neurosci 23 : 5496-5502. Medline

Williams LR, Aroniadou-Anderjaska V, Qashu F, Finne H, Pidoplichko V, Bannon DI, Braga MF (2011) RDX binds to the GABA(A) receptorconvulsant site and blocks GABA(A) receptor-mediated currents in the amygdala: a mechanism for RDX-induced seizures. Environ Health Perspect 119:357-363. CrossRef Medline

Womble MD, Moises HC (1993) Hyperpolarization-activated currents in neurons of the rat basolateral amygdala. J Neurophysiol 70:2056-2065. Medline

Woodruff AR, Sah P (2007) Networks of parvalbumin-positive interneurons in the basolateral amygdala. J Neurosci 27:553-563. CrossRef Medline

Wu LJ, Ko SW, Toyoda H, Zhao MG, Xu H, Vadakkan KI, Ren M, Knifed E, Shum F, Quan J, Zhang XH, Zhuo M (2007) Increased anxiety-like behavior and enhanced synaptic efficacy in the amygdala of GluR5 knockout mice. PLoS One 2:e167. CrossRef Medline

Xiong ZQ, Stringer JL (2000) Extracellular pH responses in CA1 and the dentate gyrus during electrical stimulation, seizure discharges, and spreading depression. J Neurophysiol 83:3519-3524. Medline

Zha XM, Wemmie JA, Green SH, Welsh MJ (2006) Acid-sensing ion channel la is a postsynaptic proton receptor that affects the density of dendritic spines. Proc Natl Acad Sci U S A 103:16556-16561. CrossRef Medline

Zhou R, Wang S, Zhu X (2010) Prenatal ethanol exposure attenuates GABAergic inhibition in basolateral amygdala leading to neuronal hyperexcitability and anxiety-like behavior of adult rat offspring. Neuroscience 170:749-757. CrossRef Medline

Ziemann AE, Schnizler MK, Albert GW, Severson MA, Howard MA 3rd, Welsh MJ, Wemmie JA (2008) Seizure termination by acidosis depends on ASIC1a. Nat Neurosci 11:816-822. CrossRef Medline

Ziemann AE, Allen JE, Dahdaleh NS, Drebot II, Coryell MW, Wunsch AM, Lynch CM, Faraci FM, Howard MA 3rd, Welsh MJ, Wemmie JA (2009) The amygdala is a chemosensor that detects carbon dioxide and acidosis to elicit fear behavior. Cell 139:1012-1021. CrossRef Medline 